\title{
O DESENVOLVIMENTO DA CRÍTICA HUSSERLIANA AO PSICOLOGISMO APÓS AS INVESTIGAÇÕES LÓGICAS
}

Mário Ariel González Porta ${ }^{1}$

Pontifícia Universidade Católica - São Paulo

\section{Introdução}

Que exista uma importante virada no tratamento husserliano da temática do psicologismo após 1900, é algo que não foi negligenciado por nenhum investigador que se tenha ocupado em mínima medida com o tema. Não obstante, todos eles, quase sem exceção, tratam a posição de Husserl após 1900 como se fosse única, sendo comum que as análises se apoiem, sem mais, em textos de épocas muito diferentes. É neste ponto que desejamos nos concentrar, apresentando uma análise diferenciada dos períodos do desenvolvimento da crítica ao psicologismo após 1900, sem a qual é inviável uma consideração sistemática razoável. É posssivel diferenciar sete momentos no desenvolvimento do tratamento husserliano do problema do psicologismo:

a. 1894-1898: o psicologismo inicial da psicologia descritiva pré-fenomenológica, expresso na Filosofia da Aritmética e que provocou a conhecida reação de Frege;

b. 1900: a crítica do psicologismo concentrada na lógica nas Investigações Lógicas;

c. 1901-1902: a mudança do centro de interesse do psicologismo lógico para o epistemológico;

d. 1903: o abandono da determinação da fenomenologia como psicologia descritiva e a substituição por sua determinação como psicologia eidética;

\footnotetext{
${ }^{1}$ Bolsista da Capes Proc. . $^{\circ}$ BEX 0423/10-6.
} 
e. 1906-1907: a virada transcendental e a descoberta da redução fenomenológica. Começo da crítica do psicologismo transcendental;

f. 1927: a compreensão e a superação final e definitivas do psicologismo transcendental;

g. 1936: o abandono da ideia do psicologismo transcendental na versão final e definitiva.

A periodização indicada constitui o fio condutor de nossa exposição e orienta a análise sistemática. No entanto, nossa exposição não se articula, sem mais, com base nos períodos assim diferenciados, e isto pelo seguinte motivo: a crítica do psicologismo é um dos temas centrais do pensamento de Husserl. Isto nos obriga, inevitavelmente, a ter que considerá-la no interior de um contexto que a transcende, já que ela se cruza com várias outras questões, a saber:

a. a ideia de psicologia, que compreende, em particular, a ideia de psicologia pura ou fenomenológica;

b. a teoria da redução e, em particular, dos chamados caminhos ou vias (Wege) para a mesma;

c. a teoria da auto constituição da subjetividade;

d. a doutrina das ontologias regionais;

e. a fundamentação das ciências do espírito;

f. a teoria do mundo da vida;

g. a análise da consciência do tempo imanente;

h. a fenomenologia genética $\mathrm{e}$

i. as relações entre lógica e teoria do conhecimento.

Em todos os temas indicados existe uma evolução própria, certamente não desconexa daquela da crítica do psicologismo (e dos outros temas vinculados), porém, não simplesmente a ela paralela. Por tal razão, e para não interromper repetidamente com observações o fio da exposição principal, introduzimos dois Intermezzos nos quais abordamos em detalhe o desenvolvimento de três dos temas mencionados. Os restantes receberam menções esparsas no transcurso do texto. A relação de todos esses temas com a evolução da crítica ao psicologismo será estabelecida nos itens nos quais o percurso da mesma será desenvolvido. 


\section{Primeiro momento: 1900. A crítica do psicologismo nas Investigações Lógicas}

Para seguir o desenvolvimento que anunciamos, deixaremos de lado o primeiro momento do percurso husserliano e começaremos com as Investigações Lógicas. Não repetiremos mais uma vez, porém, "a história infinita" (die unendliche Geschichte), isto é, não efetuaremos uma análise que acompanhe os Prolegômenos, mas nos limitaremos a sublinhar alguns pontos com base nos seguintes critérios:

a. eles são essenciais para a evolução posterior, seja porque simplesmente a determinam, seja porque experimentam uma modificação significativa;

b. eles não são adequadamente destacados pela crítica.

Os Prolegômenos contêm uma refutação argumentativa do psicologismo lógico. Isto só é possível porque a lógica é considerada como uma disciplina autônoma. Este não será mais o caso quando Hụsserl passa a ressaltar a necessidade de uma fundamentação transcendental da lógica formal.

A refutação argumentativa do psicologismo lógico nos Prolegômenos consiste basicamente em mostrar que o psicologismo çonduz a um contra senso (Widersinn). O essencial é, não obstante, como isto acontece, a saber, com uma argumentação que se desenvolve em dois passos. Primeiramente Husserl mostra que o psicologismo conduz ao relativismo; em seguida, que o relativismo, que necessariamente é cético, é um contra senso. Ora, à tese de que o psicologismo conduz ao relativismo é essencial o fato que se subentenda que a psicologia em questão é uma ciência natural. ${ }^{2}$ Isto significa, mais concretamente, que a psicologia é uma ciência explicativo-causal que, por estå razão, procede de modo empírico-indutivo. ${ }^{3} \mathrm{Em}$ suma, as Investigações Lógicas pressupõem, sem mais, que só uma concepção cientifico-natural da psicologia pode dar lugar ao psicologismo.

A refutação do psicologismo nas Investigações Lógicas não é de forma alguma levada a termo nọs Prolegômenos, como poderia parecer se nos abandonássemos às análises especializadas. Pelo contrário, o segundo volume das Investigações Lógicas também é parte essencial de tal refutação. A relação entre ambos os volumes não é, portanto, a de que o primeiro contém a crítica do psicologismo, enquanto o segundo traz o complemento positivo, ou seja, uma teoria da subjetividade. Observar isto é fundamental, pois algumas das novidades no desenvolvimento posterior da crítica antipsicologista concernem

\footnotetext{
2 Hua Briefwechsel, Band III, 131.

${ }^{3}$ Ver item 6.2.
} 
especialmente às posições defendidas no segundo volume. A argumentação dos Prolegômenos será posteriormente considerada unilateral e insuficiente, mas não sofrerá modificações e, na consciência da sua limitação, será mantida.

Quando não se passa por alto o fato de que a crítica do psicologismo nas Investigações Lógicas não se limita aos Prolegômenos, então resulta claro que a obra não se ocupa meramente com o psicologismo lógico, mas também com o epistemológico. Isto é dito expressamente por Husserl em duas oportunidades, mas negligenciado por seus críticos. ${ }^{4}$

A epistemologia das Investigações Lógicas é, não obstante, primariamente uma epistemologia da lógica e trata exclusivamente de objetos ideais. Assim, pois, se por "psicologismo lógico" se entende um psicologismo em relação a objetos abstratos, então as Investigações Lógicas tratam unicamente do psicologismo lógico. Mas se entendemos por "psicologismo lógico" tão somente um psicologismo na lógica, com exclusão da epistemologia, então as Investigações Lógicas tratam não só do psicologismo lógico, mas também do epistemológico.

Apesar de não haver nada de reprovável em se falar do "psicologismo lógico" como um psicologismo referente a objetos ideais, não faz absolutamente qualquer sentido dizer que o psicologismo epistemológico é um psicologismo referente unicamente a objetos reais. Sob nenhuma consideração se pode identificar a oposição entre lógica e epistemologia com a oposição entre objetos ideais e reais.

O psicologismo lógico, no modo em que ele é entendido nas Investigações Lógicas, conduz ao psicologismo epistemológico não só porque psicologiza o conhecimento de objetos ideais, senão porque - já que também o conhecimento do real supõe o ideal - psicologiza o conhecimento do real.

A princípio, e fora da tese de que todo conhecimento envolve objetos ideais, as Investigações Lógicas desconsideram a possibilidade do conhecimento do real. Isto, entretanto, não significa que Husserl então aceite um psicologismo com respeito a objetos reais, o que seria certamente incompreensivel, mas que Husserl é consciente de que o argumento que ele usa para refutar o psicologismo em relação a objetos ideais não é pertinente quando se trata de objetos reais. Enquanto limita a crítica do psicologismo a afirmação de objetos ideais, Husserl distingue o ceticismo epistemológico do metafísico, observando que só o primeiro, e não o segundo, pode ser considerado justificadamente um contra senso. ${ }^{5}$

${ }^{4}$ Hua XVIII, 7; Hua XIX/I, 112. Cf. Hua Briefwechsel, Band III, 131.

5 Hua XIX/II, 725 sgs. 
A origem do psicologismo concernente a objetos ideais repousa na natureza peculiar de ditos objetos, isto é, no fato de que os mesmos não podem ser percebidos sensivelmente. Desta maneira, o problema do psicologismo de objetos ideais não é senão mais um capítulo na antiga querela dos universais. Como mostram claramente a primeira e segunda investigação lógica, o problema de base é a possibilidade ou impossibilidade de captar objetos abstratos.

A contribuição do segundo volume das Investigações Lógicas à luta antipsicologista é múltipla:

a. a abstração eidẹtica se opera não sobre atos, mas sobre o conteúdo de atos; ${ }^{6}$

b. a teoria da intuição categorial é fundamentada eideticamente e vale, portanto, para toda consciência; ${ }^{7}$

c. deve-se diferenciar entre conteúdo real (reell) e ideal ${ }^{8} \mathrm{e}$, sobretudo,

d. a refutação da teoria empirista da abstração deve ser alcançada através da posta de manifesto da existência de uma intuição eidética. ${ }^{9}$

Este último ponto é absolutamente determinante. O núcleo da crítica do psicologismo epistemológico radica em evidenciar que a descrição empirista da subjetividade, sobre a qual ele se apoia, é falsa. Em última instância, o psicologismo epistemológico é refutado de modo descritivo. Trata-se de mostrar que ele repousa sobre uma teoria da subjetividade que não efetua as distinções necessárias. ${ }^{10}$ Como consequência, a refutação do psicologismo deve ser assumida por uma psicologia descritiva.

Disto se segue que a realidade do sujeito em questão é um dado essencial do problema abordado no segundo volume das Investigações Lógicas. Não se deve esquecer o importante prefácio, em que Husserl manifesta claramente que o problema a ser tratado é como um sujeito real é capaz de aceder a algo ideal. ${ }^{11}$ Dito de outra forma, trata-se de explicar como é possível que, no conhecer; o ideal "flua" no real.

O fato de a crítica do psicologismo nas Investigações Lógicas se ocupar exclusivamente com objetos. ideais, vincula-se ao fato de Husserl não situar

${ }^{6}$ Hua XIX/I, 667; resposta a Frege.

${ }^{7}$ Hua XIX/II, 725 sgs.

${ }^{8}$ Hua XIX/I, 411.

${ }^{9}$ Hua XIX/I, 113 sgs.

10 Hua XIX/I, 11.

${ }^{11}$ Hua XVIII, 7; Hua XIX/I, 8, 26 sgs. Problema este coerente com a "solução" proposta pela primeira Investigação Lógica, que remete a relação ideal-real à relação espécies-instância. 
o "principio de imanência" 12 como origem do mesmo. Coerentemente com o anterior, Husserl distingue nas Investigações Lógicas o problema do psicologismo do problema do idealismo. ${ }^{13}$ Tudo isto deverá mudar com a virada à fenomenologia transcendental. ${ }^{14}$

Ainda que, em nossa opiniã̀o, esteja fora de dúvida a influência de Frege no surgimento das Investigações Lógicas, existem três diferenças importantes entre a posição de Husserl e a de seu crítico. ${ }^{15}$

a. Husserl não menciona o princípio de imanência como pressuposto fundamental do psicologismo.

b. Husserl não identifica psicologismo e idealismo.

c. O tratamento que Husserl outorga a Erdmann é totalmente diferente do fregeano. Em nenhum momento Husserl considera como erro fundamental de Erdmann a pressuposição do princípio de imanência. Esta não centralização no princípio da imanência está em relação com uma reformulação incipiente do mesmo sobre a base da distinção entre conteúdo real (reell) e intencional.

Após 1906, Husserl se aproxima de Frege nos dois primeiros pontos mencionados através de um desenvolvimento do terceiro.

\section{Segundo momento: 1902-1903. As Lições sobre epistemologia geral}

As Investigações Lógicas trouxeram uma nova ideia de teoria do conhecimento como fenomenologia a partir de uma nova determinação da essência do conhecimento como "síntese de preenchimento". Porém, as Investigações Lógicas pressupõem de fato uma nova ideia de epistemologia sem refletir sobre ela explicitamente. Tal reflexão acontecerá a partir dos anos 1902-1903. O interesse principal de Husserl se volta agora para a determinação da essência da epistemologia, o que equivale a determinar corretamente o autêntico problema desta disciplina. ${ }^{16}$

12 Seguindo Husserl, entendo por "princípio de imanência" a expressa tese lockeana de que meus únicos objetos são as minhas próprias ideias. Salvo observação em contrário, uso o termo somente neste sentido. Sem dúvida, poder-se-ia diferenciar variantes no mesmo, como a exposta nas Investigações Lógicas, mediante a distinção entre conteúdo real (reell) e intencional, ou aquela possibilitada pela própria redução.

13 Hua XVIII, 120-121.

14 Ver item 5.

15 Estas diferenças estão presentes propriamente a partir de 1893.

${ }^{16}$ Hua Materialien, III, 8 sgs., 60,75 sgs. 
Com isto se transfere o centro de atenção da lógica para a epistemologia. $\mathrm{O}$ que nas Investigações Lógicas estava em primeiro plano, passa a segundo e vice-versa. Como consequência, o tema do psicologismo epistemológico começará a subsumir o do psicologismo lógico. Porém, nas Lições sobre epistemologia geral Husserl ainda repete a refutação do psicologismo oferecida nos Prolegômenos.

É através de uma focalização da reflexão sobre o problema da epistemologia que Husserl se vê impulsionado ao descobrimento da redução e, consequentemente, à virada transcendental. Neste sentido, as Lições do inverno 1902-1903 constituem um verdadeiro ponto de clivagem, o amadurecimento de cujos resultados manifestar-se-ão a partir de 1906-1907. Não por casualidade, quando Husserl introduz a noção de redução, esta é inicialmente qualificada de "epistemológica". ${ }^{17}$ Quando se formula corretamente o problema epistemológico torna-se óbvio que a epistemologia deve efetuar a redução e deixar de lado a existência. ${ }^{18}$

\section{Terceiro momento: 1903. Fenomenologia como psicologia eidética}

Pouco depois da publicação das Investigações Lógicas Husserl enfrenta uma dura reação em duas frentes. Os psicologistas o criticam por seu platonismo; os antipsicologistas, por sua vez, insistem na pretensa inconsequência do segundo volume da obra mencionada, no qual o paladino do anti psicologismo recairia no psicologismo ao efetuar uma fundação psicológica (ainda que "descritiva") da lógica. ${ }^{19}$ Através desta crítica Husserl se vê obrigado a abandonar à determinação da fenomenologia como "psicologia descritiva" e a substituí-la por "psicologia eidética". ${ }^{20}$ A primeira determinação, que se apoia na oposição entre análise descritiva e genético-causal, é infeliz, pois produz a impressão de que se trata de uma oposição entre duas disciplinas igualmente empíricas que apenas se distinguem pelo diferente modo de experiência em jogo em cada uma delas. A fenomenologia, porém, não é uma disciplina que se ocupa com algum tipo de fatos, seja para descrevê-los, seja para explicá-los, senão uma análise de essência e, por consequência, a priori.

Neste desenvolvimento é de extrema importância observar que, a partir de agora, Husserl começa a perceber que a ameaça do psicologismo não é algo

\footnotetext{
17 Hua XXIV, 214.

18 Hua XXIV, 401.

19 Hua XXII, 152.

${ }^{20}$ Hua XXII, 206.
} 
do qual a própria fenomenologia esteja livre e, portanto, a crítica a ele deve ser efetuada também com respeito a si mesma.

Husserl insiste, a partir de 1903, em uma leitura retrospetiva das Investigações Lógicas a qual, embora compreensivel em suas razões fundamentais, não deixa de ser anacrônica. Segundo esta leitura, já as Investigações Lógicas eram, na sua intenção fundamental, e apesar de algumas formulações equívocas, uma ciência eidética. Mas é claro que, para um leitor imparcial, o problema não radica numa denominação infeliz do projeto mas, pelo contrário, esta seria a ele adequada. Como vimos (item 2), apesar da análise da essência do conhecimento, o problema das Investigações Lógicas contém como um de seus dados fundamentais o caráter real do sujeito em questão. ${ }^{21}$ Será somente a partir de 1906 que, pela confluência dos resultados dos dois períodos anteriores, esta situação irá mudar.

\section{Quarto momento: 1906-1907. A virada transcendental}

Se em 1902 estava claro que o problema principal da teoria do corihecimento era a correta formulação da sua pergunta, em 1906-1907 Husserl é capaz de perceber que ele consiste numa relação de essências entre subjetividade e objetividade e não em afirmações factuais sobre o vínculo de um sujeito real a um objeto.

O psicologismo epistemológico deriva de uma falsa formulação do problema da epistemologia que, em vez de ser colocado como uma relação de essências, concebe um de seus termos, o sujeito, como sendo necessariamente real e, portanto, psicológico. Ó psicologismo é, pois, a consequência de uma formulação equivocada do problema epistemológico..$^{22}$

Se, já a partir de 1900, vale no pensamento de Husserl que uma autêntica epistemologia só é realizável como fenomenologia, a- partir de 1906 tornar-se-ão claros tanto que uma autêntica fenomenologia só pode ser transcendental, como que uma autêntica filosofia transcendental só pode ser fenomenológica. ${ }^{23}$

Com a virada da fenomenologia à filosofia transcendental surge o problema do psicologismo transcendental ou, melhor dizendo, apenas agora este pode ser reconhecido como tal. O psicologismo tem uma "motivação transcendental" ou possui um "núcleo de verdade transcendental" porque parte corre-

21 Vide as modificações que Husserl introduz no texto da segunda edição.

22 Hua XXIV, 143.

${ }^{23}$ Hua XXIV, 216 sgs. No numeral 6.1.3. vinculamos expressamente o caráter eidético é transcendental da epistemologia que, nesta primeira apresentação, permanecem não conexos. . 
tamente do princípio de que todo objeto deve necessariamente constituir-se na consciência. Não obstante, concebe equivocadamente esta última como psicológica. Dito de outra forma, o psicologismo transcendental é a consequência da falsa remissão do problema transcendental à psicologia derivada de uma interpretação inadequada do princípio de imanência. ${ }^{24}$

A partir de agora, Husserl usará indistintamente as expressões psicologismo transcendental e psicologismo epistemológico. ${ }^{25} \mathrm{~A}$ inobservâncià deste fato tem provocado uma confusão terminológica na literatura husserliana à qual o próprio Husserl contribuiu de modo decisivo com uma indicação retrospetiva infeliz, em Lógica Formal, Lógica Transcendental, ${ }^{26}$ segundo a qual as Investigações Lógicas abordavam corretamente o problema do psicologismo lógico, mas não percebiam, não obstante, o problema do psicologismo na sua forma mais universal, i.e., como psicologismo epistemológico. Por tal razão, é necessária uma precisão. Como observamos, ${ }^{27}$ já as Investigações Lógicas combatem não só o psicologismo lógico, mas também o epistemológico, não sendo aqui que se encontra a diferença com a posição posterior. $O$ ponto é que a distinção psicologismo lógico-psicologismo epistemológico pode indicar ou uma distinção puramente temática, referida à esfera dos objetos em questão, ou uma sistemática, que envolve uma conceção específica referente à natureza essencial do problema epistemológico como implicando necessariamente uma redução. Ao se fazer esta distinção se observa que, no segundo caso, há uma equivalência entre o conceito de psicologismo epistemológico e transcendental que não existe no primeiro. Vinculadas a esta imprecisão básica se encontram numerosas outras como, por exemplo, a confusa sobreposição da crítica do psicologismo transcendental a partir de 1906 com a crítica da psicologia transcendental nas Investigações Lógicas. ${ }^{28}$

A redução enquanto tal não é, a princípio, outra coisa que o método para o acesso intuitivo ao sujeito transcendental e, por consequência, para o ingresso na esfera de investigação da fenomenologia transcendental. ${ }^{29}$ Ora, a fixação da subjetividade transcendental consiste primariamente em delimitar a mesma da subjetividade psicológica. Por tal motivo, a redução é ao mesmo tempo o procedimento de acesso metódico à esfera da filosofia transcendental e da

24 Hua XXIV, 166 sgs., 201 sgs.

${ }^{25}$ Hua XXV, 12-13; Hua XVII, 136.

26. Hua XVII, 137.

27 Ver item 2.

28 Analisamos essas ambigüidades no nosso artigo "Algunas consideraciones en torno a la distinción de tipos de psicologismo en Husserl".

${ }^{29}$ Hua IX, 315. 
delimitação de subjetividade psicológica e transcendental. Portanto, a redução é o meio de superação do psicologismo. ${ }^{30}$

Com a virada à fenomenologia transcendental, o problema do psicologismo no âmbito da fenomenologia experimenta uma transformação radical. O psicologismo, ao qual as Investigações Lógicas se opunham, consistia primariamente numa redução das estruturas ideais a psicológicas. $\mathrm{O}$ seu combate implicava, por isso, duas tarefas. Tratava-se, por um lado, de evidenciar a independência das estruturas ideais do sujeito psicológico e, por outro, de tornar compreensível a relação das mesmas com este sujeito, ou seja, de dar conta da possibilidade da sua apreensão. Quando da virada transcendental, a refutação do psicologismo já não consistirá na distinção entre objetos ideais e sújeito psicológico, mas primariamente na distinção entre subjetividade psicológica e transcendental.

Vimos que, em 1903, o problema do psicologismo continha como um de seus momentos a própria fenomenologia. A partir de 1906 Husserl é capaz de compreender que, ainda que as Investigações Lógicas combatessem corretamente o psicologismo lógico, ficavam presas ao epistemológico ${ }^{31}$ ou, numa outra formulação, que mesmo tendo elas superado adequadamente o naturalismo das ideias, estavam presas ao naturalismo da consciência. ${ }^{32}$

Em suma, se inicialmente, nos Prolegômenos, Husserl se propôs a refutar o psicologismo, por experiência própria teve que apreender que uma refutação do psicologismo está longe de garantir a sua autêntica superação. Devemos, pois, diferenciar entre refutação e superação do psicologismo, por um lado, e entre refutação argumentativa e descritiva do mesmo, por outro. As Investigações Lógicas efetuam uma refutação do psicologismo que, mesmo tendo em si mesma seu valor, foi, não obstante, incapaz de propriamente superá-lo. O desenvolvimento posterior de Husserl estará marcado, já não pelo intento de refutação, mas pelo intento de superação, superação que, como observado no item 4 , incluirá como momentò essencial uma autocrítica da própria fenomenologia.

30 Hua XXIV, 209 sgs.

31 Ver item 4.

${ }^{32}$ Hua XX, 9. 


\section{Intermezzo I}

\subsection{O desenvolvimento da ideia de psicologia}

É sabido que Husserl modifica a sua própria autocompreensão do que seja a fenomenologia no transcurso do tempo. Somente com o intuito de esboçar esse desenvolvimento, lembremos que a fenomenologia é primeiramente concebida como psicologia descritivá, logo como psicologia eidética e, finalmente, como filosofia transcendental, primeiro estática edepois genética.

As mudanças na conceção husserliana do que seja a fenomenologia estão em correlação com as mudanças em sua conceção do que seja a psicologia. A forma em que Husserl concebe a fenomenologia acompanha a forma em que concebe a psicologia e vice-versa, de modo tal que a cada etapa na autocompreensão da fenomenologia corresponde uma etapa na compreensão da psicologia. Isto não é uma pura casualidade, senão a consequência da estreita relação que existe entre essas disciplinas. Consideremos esta situação mais detidamente.

A fenomenologia só pode se estabelecer como disciplina específica e, mais ainda, como disciplina propriamente filosófica, se delimitada da psicologia, ou seja, se responde de modo adequado e satisfatório à pergunta pela sua especificidade face à psicologia. A delimitação frente à psïcologia é para a fenomenologia uma questão que diz respeito ao seu próprio sentido e direito a existência. Não por outra razão, a luta antipsicologista é absolutamente necessária para a fenomenologia.

Mas, o fato de que o surgimento da fenomenologia se encontra em essencial relação com a crítica do psicologismo, conduziu a que, pouco depois do aparecimento dos Prolegômenos, se difundisse a opinião de que a fenomenologia era inimiga, não já do psicologismo, mas da própria psicologia. Frente a esta situação, Husserl se viu obrigado muito cedo a sublinhar que se, por um lado, a fenomenologia devia ser delimitada frente à psicologia, por outro, ela trazia consigo uma possibilidade de renovação para esta última. Mais ainda, Husserl defende a tese de que só a fenomenologia possibilita a completa realização da ideia da psicologia. Esta convicção será mantida por Husserl até a sua morte ainda que, como veremos, seu sentido e suas consequências experimentem profundas modificações no transcurso do tempo. Vejamos, então, quais são as fases na evolução da ideia de psicologia.

\subsubsection{Psicologia descritiva: 1900}

Nas Investigações Lógicas a fenomenologia traz consigo não só a possibilidade de uma nova psicologia, mas ela entende a si mesma como tal. 
A oposição principal é a oposição entre psicologia descritiva e psicologia científico-natural.

A noção de psicologia científico-natural desempenhou um papel decisivo em todo o desenvolvimento de pensamento husserliano e, por tal mótivo, convém nos deter nela. Husserl fala indistintamente de psicologia científica, científico-natural, experimental, causal, genética, explicativa, teórica e, inclusive, de psicofísica. Essas determinações têm um forte vínculo interno, embora não sejam imediatamente idênticas. Como já fizemos, falaremos primariamente de "psicologia científico-natural" e referiremos todas as outras denominações a esta com a finalidade de explicitar as suas relações. Duas ênfases podem ser destacadas em tal noção, cada uma das quais outorga um diferente sentido à sua oposição à psicologia descritiva. A psicologia científico-natural é, ao mesmo tempo, teórica e causal. A psicologia descritiva não pretende ser teoria, isto é, não visa conter construções hipotéticas que fundam pretensões explicativas. Uma ciência teórica e explicativa, por sua vez, é necessariamente causal e, eventualmente, genética. Em suma, o denominador comum de todas as noções de psicologia científico-natural é o conceito de causalidade. Ora, quando Husserl se refere à psicologia científico-natural sem maiores esclarecimentos, ele entende duas coisas em princípio diferenciáveis. Por um lado, trata-se de uma psicologia introspetiva que, seguindo o modelo do empirismo inglês, apela para a particularidade de uma dada experiência cujas leis especificas tenta determinar. Como se sabe, as leis da associação são consideradas como as leis básicas e mais gerais de tal experiência. Husserl, não obstante, identifica às vezes a psicologia científico-natural com a psicofísica, algo usual no contexto da virada do século. Neste caso, a ênfase se transfere de uma legalidade psicológica específica para a relação entre fenômenos psicológicos e físicos, no âmbito de uma orientação geralmente reducionista. Essas aparentes oscilações husserlianas na verdade põem em relevo o ponto realmente essencial. O que define a psicologia científico-natural é a sua aspiração causal. Uma ciência natural não-causal é para Husserl, com razão, um contra senso. Ora, para Husserl também se encontra fora de dúvida que a ciência natural pressupõe a unidade da natureza e, em consequência, a existência de um emaranhado causal único e totalizante. Neste sentido, ainda que ele admita a ideia de leis especificamente psicológicas, como, por exemplo, as já mencionadas de associação, não duvida que tais leis devam ser integradas na trama única da legalidade da natureza e, por consequência, em última instância, referidas a leis propriamente físicas. Por esta razão, Husserl às vezes distingue e às vezes nivela psicologia científico-natural e psicofísica pois, para ele, está fora de dúvida que uma psicologia científico-natural necessariamente remete à psicofisica. 
Se em 1900 o conceito de causalidade traça a linha divisória entre psicologia descritiva e causal, a partir de 1912 Husserl introduzirá a ideia de uma causalidade psicológica específica, i.e., a motivação, de forma que a oposição entre causalidade e não-causalidade se transfere para a oposição entre dois tipos de causalidade. Este novo tipo de causalidade, a motivação, não exclui a intencionalidade da consciência senão que, muito pelo contrário, a pressupõe. Assim, a relação entre psicologia científico-natural e descritiva se torna mais complexa. As próprias leis da associação, inicialmente consideradas como o modelo de legalidade psicológica específica, irão experimentar uma revisão no que diz respeito ao seu sentido fundamental.

\subsubsection{Psicologia eidética: 1903}

Sabemos que, por volta de 1903, Husserl abandona a determinação da fenomenologia como psicologia descritiva e a substitui pela determinação como psicologia eidética. ${ }^{33}$ Mediante esta mudança se sublinha, por um lado, o caráter não-empírico da fenomenologia, e; por outro, se introduz a ideia de que determinação a priori e psicológica não são excludentes, uma ideia que terá um papel essencial nas reviravoltas posteriores que experimentará a crítica do psicologismo.

Essencial é, assim mesmo, o fato de quie Husserl considera que basta ressaltar o caráter a priori da fenomenologia para assegurar a sua autonomia, como também para combater vitoriosamente o psicologismo. Esta, certamente, é uma ideia básica que surge com as Investigações Lógicas. O psicologismo é produto de uma conceção empírica da subjetividade. Por conseguinte, trata-se de sublinhar a oposição entre empírico e a priori ou, mais concretamente, de sublinhar a existência de uma necessidade não-empírica, mas eidética. Dado que as leis referentes às estruturas da intencionalidade são eidéticas, e não empíricas, elas valem para toda consciência em geral.

\subsubsection{Psicologia eidética e/ou pura I: 1906}

Até este momento, a fenomenologia nutriu a psicologia à medida que ela mesma se concebia como uma nova forma de psicologia, primeiro descritiva, em seguida eidética. A partir de 1906 essa situação se modifica: agora a fenomenologia possibilitará uma nova psicologia frente a qual terá que, ao mesmo

33 Ver item 4. 
tempo, se diferenciar. ${ }^{34}$ Enquanto em 1903 fenomenologia e psicologia eidética se identificam, a partir de 1906 serão diferenciadas.

Já mencionamos o fato de que com a virada transcendental começa a ficar retrospetivamente claro para Husserl que a psicologia descritiva das Investigações Lógicas estava presa ao naturalismo. ${ }^{35}$ Isso significa, na realidade, tomar consciência de que a superação do naturalismo não exige meramente uma redução eidética, mas também uma propriamente transcendental. Os dois aspetos da questão devem ser considerados detidamente. Um tratamento claro dos mesmos é oferecido por Husserl em Ideias I, na qual ele distingue duas oposições, a saber, entre fato e essência, por um lado, e entre mundano e transcendental, por outro. É sobre essa base que, em uma passagem decisiva para o nosso tema, Husserl observa que se, por um lado, lhe foi possível com relativa facilidade distinguir entre fato e essência, por outro, só com grandes esforços foi capaz de perceber que existe uma diferença decisiva entre essências objetivas e subjetivas, ou seja, entre essências que se referem à subjetividade transcendental e essências mundanas que devem ser objeto de ontologias regionais específicas. ${ }^{36} \mathrm{E}$ a este último grupo que pertence a essência do psíquico. Somente uma vez que se tem clareza sobre o ponto anterior é então possível, ulteriormente, compreender a necessidade de distinguir a fenomenologia (transcendental) não apenas da psicologia empírica, mas também da eidética.

Se deixamos de lado a relação da psicologia com a fenomenologia, e nos atemos à ideia de psicologia, pode-se pensar que, a princípio, as posições de 1903 e 1906 são idênticas, dado que, afinal de contas, em ambos casos a psicologia é entendida como ciência eidética. Não obstante, há uma diferença essencial entre ambas. Quando Husserl, após 1906, fala de uma psicologia eidética, pensa esta noção no âmbito da ontologia regional e, consequentemente, como delimitada por um abismo de sentido da fenomenologia transcendental. ${ }^{37}$ Esta distinção estava totalmente ausente em 1903.

$\mathrm{O}$ anteriormente explicitado nos remete à necessidade de distinguir entre uma "mera" psicologia eidética e uma psicologia pura (que também é eidética). A ideia de psicologia pura só faz sentido no âmbito abrangente de uma teoria da ontologia regional. Dado que existe uma relação essencial entre psicologia pura e ontologia regional, fica claro, portanto, que o desenvolvimento

${ }^{34}$ Hua XXIV, 240 sgs., 380 sgs.

${ }^{35}$ Ver item 5.

${ }^{36}$ Hua III, I, 122.

${ }^{37}$ O percurso expositivo de Ideias I é uma prova clara do que vínhamos dizendo e da sua importância para Husserl. 
das ontologias regionais a partir de Ideias I traz consigo consequências decisivas para a ideia de psicologia pura.

Mas o que é a psicologia pura? Enquanto a ciência da natureza se constitui como tal a partir da época moderna, a psicologia do começo do século $\mathrm{XX}$ ainda luta para adquirir este status. A fenomenologia, surgida inicialmente como refundamentação da filosofia, proporciona ao mesmo tempo as bases da almejada psicologia científica. A precisão de uma ciência de fatos não se conquista meramente através de seus métodos empíricos, mas da fixação precisa de seus conceitos fundamentais. A superação da situação de desvantagem da psicologia em relação às ciências da natureza, só é possível mediante o cumprimento de tal tarefa. Isto exige o estabelecimento de uma disciplina específica, a psicologia pura. Ela é pura enquanto considera o psíquico em sua especificidade e radical diferença de tudo o que é físico. A ideia do psíquico puro, porém, não é, a princípio, mais que um problema e a questão a ser resolvida é propriamente a determinação da sua possibilidade. O caráter fundamental do psíquico é a intencionalidade ou, dito de outro modo, a síntese particular que a mesma opera. O ser do psíquico, enquanto intencional, não é outra coisa que o ser do fenômeno. Uma psicologia pura, portanto, não é outra coisa que uma psicologia autenticamente fenomenológica.

Apesar da ideia de uma psicologia pura se delinear já claramente a partir de 1906, a expressão é introduzida em data posterior. Esta observação terminológica necessária nos conduz a outras que estão a ela relacionadas. Husserl utiliza uma longa série de expressões para se referir à ideia de psicologia pura e àquelas outras a ela vinculadas, que convém diferenciar, tais como:

a. psicologia descritiva;

b. psicologia da experiência interna;

c. psicologia eidética;

d. psicologia racional;

e. psicologia fenomenológica;

f. psicologia pura e

g. psicologia fenomenológica pura.

O termo "psicologia descritiva" é usado ao menos em três sentidos, seja para se referir ao projeto das Investigações Lógicas, seja para se referir à psicologia de Brentano e seus discípulos, seja, finalmente, para se referir à psicologia de Locke e suas derivações. Nesfe último contexto é usual encontrar a expressão "psicologia da experiência interna", ainda que tạmbém seja possível encontrar passagens nas quais Husserl fala em "psicologia fenomenológica". "Psicologia racional" e "eidética" são, a princípio, sinónimas, porém, os primeiros usos da expressão "psicologia racional" somente aparecem após 
a virada transcendental e remetem ao que depois Husserl chamará "psicologia pura", termo este que terminará substituindo totalmente o anterior. Do mesmo modo, "psicologia pura" é, a princípio, sinónimo de "psicologia fenomenológica", porém Husserl tende à usar a expressão "psicologia pura" só quando se refere ao seu próprio projeto, enquanto usa a expressão "psicologia fenomenológica" mais livremente para se referir a projetos com intenção similar (Lipps, Pfander, etc:). As nuances e diferenças são muitas vezes irrelevantes, outras, não obstante, devem ser consideradas para fixar com precisão a conceção de Husserl em um determinado momento.

Já usamos a expressão "psicologia pura" para nos referir à posição de Husserl e expusemos os motivos pelos quais a distinguimos da psicologia eidética no sentido de 1903. Não obstante, deve-se dizer que, nesta primeira versão de 1906, tanto a psicologia eidética quanto a pura coincidem em se fundar exclusivamente sobre uma redução eidética. Se Husserl já em 1906 tem claramente a ideia de uma psicologia eidética como ontologia regional diferente da fenomenologia transcendental, ele, entretanto, não possui ainda a ideia de uma redução psicológica específica. Com isto passamos à próxima etapa.

\subsubsection{A psicologia pura II: 1917-1923}

Mesmo que a ideia de uma psicologia pura já esteja esboçada a partir de 1906, Husserl só alude à mesma circunstancialmente, sem lhe dedicar uma atenção específica e um desenvolvimento pormenorizado. Esta situação muda em torno de $1917,{ }^{38}$ quando ele, pela primeira vez, dedica um ensaio específico ao tratamento da relação entre a fenomenologia transcendental e a nova psicologia que ela torna possível. Ainda que muito do que Husserl dirá em 1917 se encontre disperso nos textos anteriores, no ponto mencionado se constata uma clara novidade.

Esta não é, porém, a única nem a mais importante diferença em relação ao período anterior. Em 1917 Husserl insinua a ideia de uma redução psicológica particular que constitua o meio de delimitação da esfera de investigação da psicologia pura, uma ideia que, não obstante, só será desenvolvida por extenso na Filosofia Primeira (1923-1924). ${ }^{39}$ É central o fato de que uma redução puramente eidética agora não apenas não é capaz de fundar a fenomenologia, mas tampouco é capaz de fundar a própria psicologia. Neste sentido, ainda que sejam ideias estreitamente vinculadas, convém diferenciar a formulação inicial da ideia de uma psicologia pura ou, talvez, a ideia de uma 
psicologia eidética no âmbito de uma fenomenologia transcendental, da ideia de uma psicologia pura "em sentido pleno", a qual supõe um procedimento metódico específico com a finalidade de assegurar a pureza almejada.

Sabemos que o caráter essencial do psíquico é a intencionalidade. Porém, o puramente psíquico não é algo que se ofereça sem mais e por si mesmo na experiência. $O$ psíquico se apresenta originalmente apenas na reflexão, e nela, inicialmente, em um vínculo estreito com o corpo. Por isso, é necessário um método através do qual seja assegurada a distinção do psíquico de tudo aquilo que não é psíquico. Este método não é outra coisa que a redução psicológica. Através dela o psicólogo suspende toda posição de existência daquilo de que se é consciente, e dessa forma o objeto permanece só como correlato. ${ }^{40}$ Somente através desta redução é possível delimitar uma esfera autónoma e auto referente que em nenhum momento possibilita nem exige ir além de si mesma.

No contexto do projeto de uma fenomenologia transcendental, a ideia de uma redução psicológica específica não deixa de ser um paradoxo. Afinal, a redução foi introduzida como o procedimento decisivo para distinguir entre subjetividade psicológica e transcendental. Quando se leva em conta este contexto, o conceito de uma redução psicológica não parece ser senão uma contradição entre termos. Que seja necessário um procedimento para garantir o aceso metódico ao psíquico puro, é algo que parece razoável. Que esse procedimento, não obstante, seja propriamente uma "redução" em sentido pleno, não é por si mesmo evidente. O emprego do conceito de redução neste contexto implica algo de essencial ou trata-se meramente de uma extensão do seu significado original? Se nos atemos à própria descrição que Husserl oferece em reiteradas ocasiões de este procedimento, o último não parece ser o caso. Porém, é em outra direção que Husserl aponta quando legitima tal proceder introduzindo-o como uma abstração correlativa àquela da física. Assim como a física "abstrai" de todo o psíquico, também a psicologia "abstrairia" de todo o físico. Mas trata-se de uma redução ou de uma mera abstração?

\subsubsection{Psicologia pura III: 1927}

O programa de uma psicologia pura foi introduzido em 1917 e explicitado em 1923-1924. Isto aconteceu, todavia, sempre no marco de interesses mais abrangentes. Uma situação totalmente diferente se apresenta em torno dos anos 1925-1927, data das Lições sobre Psicologia Pura, da Conferência de Amsterdam e do artigo da Enciclopédia Britânica. A novidade agora é que

${ }^{40}$ Ao estudar a fantasia ou a lembrança, por exemplo, o psicólogo deve prescindir de toda consideração da existência ou não do objeto do ato para se limitar a descrever a pura correlação intencional. 
Husserl se concentra não apenas em formular dito programa, dedicando a ele considerações metódicas, mas também em efetuá-lo, desenvolvendo exaustivamente o seu conteúdo. Já este fato obrigaria aqui a diferenciar um novo período. Entretanto há algo a mais.

Quando Husserl, por volta de 1923, introduz a ideia de uma redução psicológica, devemos tomar um cuidado especial em como ele a concebe concretamente, pois sem essa fixação não pode ser compreendido, ou inclusive percebido, o desenvolvimento posterior.

Novo em 1927 é o modo em que Husserl concebe a redução psicológica, absolutamente diferente de 1923-1924. Uma vez que ainda iremos nos ocupar amplamente com este ponto, ${ }^{41}$ digamos agora brevemente que, enquanto a redução psicológica de 1923-1924 tende a sublinhar uma passagem gradual à redução transcendental, em 1927 se insiste na descontinuidade essencial entre ambas. ${ }^{42}$

Com a clara delimitação de princípio de dois tipos de redução, Husserl introduz agora a nova ideia de uma redução eidética específica da psicologia pura e nela fundada.

A mudança na situação geral que se operou na relação entre psicologia e fenomenologia transcendental se expressa com clareza em dois pontos. Vimos que, quando Husserl introduz a redução, a qualifica de "epistemológica". Com o tempo, porém, se impõe a qualificação da mesma como "fenomenológica". Não obstante, a partir de 1927, Husserl começa a distinguir explicitamente entre uma redução psicológico-fenomenológica e uma redução fenomenológico-transcendental. Assim, o caráter "fenomenológico" não é específico de nenhuma dessas duas reduções, mas é comum a ambas. Isto é coerente com o fato de que agora Husserl concebe a fenomenologia como uma disciplina que não é em si mesma filosófica e que contém em si a psicologia pura, por um lado, a fenomenologia transcendental, por outro. ${ }^{43}$

\subsubsection{Identificação de psicologia pura e fenomenologia transcen- dental: 1936}

Ainda que desde 1906, e apesar de todas as suas variações, Husserl sublinhe que se deve distinguir entre aquela psicologia que a fenomenologia torna possível e a própria fenomenologia, essa tendência é abandonada em

41 Ver item 6.3.

${ }^{42}$ Hua IX, 278 sgs.

${ }^{43}$ Hua LX, 237. 
1936, quando se passa a ensinar explicitamente a identidade de ambas as disciplinas. ${ }^{44}$

É importante observar que esta identificação é, em sentido próprio, uma identificação e não uma negação de um dos termos. Com efeito, poderia se pensar que em 1936 Husserl simplesmente abandona a ideia de uma psicologia pura. Isto, não obstante, não seria uma formulação adequada do verdadeiro estado de coisas. O fato é justamente que o pleno desenvolvimento de uma psicologia pura conduz a que ela se identifique finalmente com a fenomenologia transcendental. Dito de outro modo, a própria distinção entre psicologia pura e fenomenologia transcendental não pode ser mantida se se desenvolve a ideia da primeira de forma consequente e se a conduz à sua plena realização. Se esta plena realização é haurida, então resulta evidente que a psicologia pura só pode ser um momento parcial na direção da fenomenologịa transcendental. ${ }^{45}$

Já com a primeira manifestação da ideia de uma psicologia pura estava presente a poșsibilidade de um intercâmbio recíproco de seus resultados com a fenomenologia transcendental. Esta ideia se mantém em todo o desenvolvimento posterior. O que vai mudando é a direção da relação. ${ }^{46} \mathrm{Em} 1906$ Husserl salienta o fato de que os conteúdos da fenomenologia transcendental podem ser retraduzidos em termos da psicologia pura e, assim, permitir seu aprofundamento. A partir de 1923, não obstante, se inverte a direção principal. Trata-se agora da possibilidade de retradução dos resultados da psicologia pura na fenomenologia transcendental. Esta ênfase no paralelismo dos conteúdos culmina em 1936 na afirmação da identidade das duas disciplinas.

\subsection{A evolução da teoria da redução}

Com o descobrimento da redução em torno de 1906-1907 começa o desenvolvimento da fenomenologia transcendental. Ora, enquanto nas suas formulações iniciais a redução aparecia como um procedimento único, nos anos seguintes vai se impondo a ideia de que se pode efetuá-la de diferentes modos ou de que são possíveis diferentes caminhos ou vias à redução. $\mathrm{O}$ que motiva Husserl a efetuar este desenvolvimento é, por um lado, a fechada resistência que encontrará entre seus discípulos e contemporâneos a acompanhá-lo em seu movimento ao idealismo - algo que ele entendera como próprio da absoluta novidade da sua proposta, que a condena irredutivelmente a mal entendidos. -. Isto conduzirá Husserl a procurar melhorar a apresentação da

\footnotetext{
44 Hua VI, 263.

45 Hua XIX, 137.

${ }^{46}$ Hua IX, 270.
} 
redução, se valendo, para isso, de formas mais pedagógicas de exposição. Outro motivo, independente do anterior, não será menos decisivo para levar Husserl à ideia das vias. As dificuldades das primeiras formulações da redução não foram meramente didáticas, mas sistemáticas, dado que tornavam Husserl incapaz de integrar metodicamente no projeto fenomenológico esferas tais como a da intersubjetividade e da temporalidade originária.

O tema dos caminhos na redução tem sido extensamente discutido na literatura husserliana. Os pontos principais da discussão ainda em curso giram em torno das seguintes perguntas:

a. Quantas vias para a redução existem e quais são elas?

b. Quais são as mais importantes ou fundamentais?

c. Que vantagens e desvantagens possui cada uma delas e, eventualmente, quais são as mais adequadas para alcançar o fim proposto?

d. Há propriamente diferenças sistemáticas irredutíveis entre as vias ou, em última instância, tudo se reduz a vantagens e desvantagens no modo de exposição?

Curiosamente, há em toda esta polémica dois pontos que permanecem sem consideração, a saber,

a. a relação entre o tema das vias com o problema do psicologismo e, em particular, do psicologismo transcendental;

b. a análise genético-evolutiva dos diferentes caminhos, algo essencial para fixar adequadamente a relação supracitada.

Neste item nos ocuparemos com a segunda questão. Começaremos a nossa análise com uma observação que pretende evitar um possível equívoco. Ainda quando não é unanimamente aceita, a posição mais influente no tema das vias para a redução, e que constitui o pressuposto ineludível de toda a discussão posterior, é aquela proposta por Kern. Segundo este autor, existem três vias básicas à redução, das quais a terceira pode ser desenvolvida em diversas variantes. Estas vias são: a via cartesiana, a via através da psicologia fenomenológica e a via através da ontologia, a qual pode se concretizar numa via através da lógica formal, das ontologias regionais ou do mundo da vida: Aceito isto, fica a princípio fora de dúvida que existe uma ordem cronológica entre as diferentes vias. Esta ordem pode ser descrita basicamente da seguinte maneira:

a. a via cartesiana surge simultaneamente com a ideia de redução, aparecendo em $A$ ideia da fenomenologia (1907), tendo um desenvolvimento decisivo em Ideias I (1913) e alcançando a sua formulação mais madura nas Meditações cartesianas (1931); 
b. a via através da psicologia é exposta pela primeira vez em Filosofia primeira, ou seja 1923-1924, e é retomada com posterioridade na "Conferência de Amsterdam", no artigo para a Enciclopédia Britânica (1927), em Lógica formal, lógica transcendental (1929), em Meditações cartesianas (1931) e em Crise (1936);

c. a via através da ontologia se insinua em $A$ ideia da fenomenologia, aparece de modo claro com o desenvolvimento das ontologias.regionais posteriores a Ideias I e assume reformulações em Lógica formal, lógica transcendental e em Crise, que a desenvolvem na direção da lógica formal ou do mundo da vida.

Disto se conclui com clareza que já é usual na literatura indicar a existência de uma cronologia das vias, sendo que a ordem estabelecida por Kern é aceita sem restrições. Em tal sentido se justifica o questionamento sobre em que medida a perspetiva evolutiva proposta por nós é efetivamente nova. Por isso convém destacar que o ponto principal radica em que na cronologia que acabamos de reproduzir se pressupõe que cada uma das vias permanece inalterada a partir da sua primeira formulação por parte de Husserl. Mas justamente não é este o caso. As vias não são valências estáticas, mas sofrem uma evolução.

No que segue não podemos desenvolver o tema indicado em toda a sua envergadura: o limitaremos à via através da psicologia fenomenológica, nela concentrando a análise. A nossa tese reza: ainda que se possa falar razoavelmente de uma via através da psicologia, no modo em que Husserl a concebe, são efetuadas decisivas variações, de modo que se deve falar ao menos de três diferentes fases ou momentos na mesma.

a. Quando a via através da psicologia é explicitamente introduzida em Filosofia primeira, Husserl formula pela primeira vez a ideia de uma redução psicológica específica e a distingue da redução propriamente transcendental. Em tal via temos primeiramente um procedimento preparatório, a redução psicológica, que delimita a esfera da psicologia pura e, sobre sua base, se constrói a redução transcendental propriamente dita. Isto será mantido na fase seguinte. Decisivo é, não obstante, observar como é entendida a redução psicológica e, correlativamente, como é fixada a sua relação com a redução especificamente transcendental. Em 1923, a diferença entre redução psicológica e transcendental se concentra na oposição entre redução singular e universal. ${ }^{47}$ A redução psicológica se caracteriza pelo fato de que ela se dirige a atos singulares, situando entre parênteses o objeto desses atos. A redução transcendental, pelo contrário, se dirige ao horizonte total do mundo. $\mathrm{O}$ modo em que 
Husserl fixa a diferença entre ambas as reduções em 1923-1924 se encontra no interior de uma tendência mais ampla que é simultânea ao surgimento da ideia de "vias". Na versão inicial da redução, Husserl sublinha o corte radical operado pela mesma, algo coerente com a diferença absoluta existente entre a atitude natural e a fenomenológica. Não obstante, Husserl deve dar conta de duas exigências opostas e igualmente decisivas. Se o caráter absoluto da distinção entre a atitude natural e a transcendental é negligenciado, coloca-se em perigo a novidade e mesmo o sentido do projeto de uma fenomenologia transcendental. Porém, se unilateralmente se insiste na distinção das atitudes mencionadas, corre-se o risco de tornar incompreensível para o iniciante o que em definitivo essa nova filosofia se propõe. Buscar alguma mediação no acesso ao plano transcendental se torna, então, necessário, e a via através da psicologia responde adequadamente a tal exigência. Por este motivo, e dentro do contexto indicado, se insiste no elemento de continuidade ou gradação entre ambas as reduções, sugerindo-se, fortemente, que o próprio desenvolvimento da redução psicológica conduz à redução transcendental através de uma ampliação paulatina de seu campo de aplicação.

b. Logo após as lições sobre Filosofia primeira, Husserl efetua uma autocrítica e abandona a ideia de que a diferença entre a redução psicológica e a transcendental possa se fundar meramente no caráter particular da primeira e universal da segunda. ${ }^{48}$ Em certo sentido, ambas as reduções são "universais" e exigem ser aplicadas irrestritamente a todo tipo de objetos. Esta "universalidade" é, não obstante, diferente: a redução psicológica situa todo objeto entre parênteses, mas desconhece o próprio ser do psicólogo, que permanece pressuposto. A diferença real entre ambas as reduções radica em que o sujeito, que opera a redução, inclua ou não a si próprio na mesma. É desta forma que a ideia de redução psicológica é desenvolvida por extenso a partir de 1927, reaparecendo posteriormente em Lógica formal, lógica transcendental e Meditações cartesianas. A sugestão de uma gradação é substituída por uma ênfase em um claro corte.

c. Ainda um terceiro momento pode ser constatado em Crise, onde a ideia de uma dupla redução é abandonada e substituída pela ideia de uma redução psicológica que, no seu desenvolvimento consequente, conduz à transcendental. Isto é totalmente coerente com o fato, já mencionado, de que em Crise se opera uma identificação final da psicologia pura e da fenomenologia transcendental. Husserl volta, então, à ideia de gradação, que primava na sua primeira formulação do caminho através da psicologia, para outorgar o primado absoluto ao que era tão-somente um momento. O ponto central é 
agora que a redução psicológica só pode ser diferenciada da transcendentả, se não é desenvolvida em total consequência, mas que, desenvolvida de esta forma, conduz necessariamente à mesma.

\section{Quinto movimento: 1927. A compreensão e superação definitiva do psicologismo transcendental}

A partir de 1927, Husserl insiste em diversas ocasiões em afirmar que a fenomenologia transcendental alcançara, então, uma compreensão última e definitiva do psicologismo transcendental, a qual torna possível, correlativamente, sua superaçãò última e definitiva. ${ }^{49}$ É crassamente notório o fato de

49 Dada a importância para o nosso tema, citamos por extenso os textos referidos. Faremos o mesmo em outras ocasiões especiais.

"Das Versagen in der radikalen Erfassung der transzendentalen Subjektivität oder, was gleich gilt, das Fehlen der Methode transzendentaler Reduktion ließ eine Scheidung zwischen dieser transzendentaler Subjektivität und der psychologischen nicht aufkommen... so musste die Psychologie der Erkenntnis zur transzendentalen Erkenntnistheorie unvermerkt sich wandeln und die Psychologie der wertenden und praktischen Vernunft zur transzendentalen Theorie der Vernunftarten. Der Psychologismus musste also ungeklärt und in kraft bleiben - ich meine der prinzipielle transzendentale Psychologismus, der für eine möglich wissenschaFTLiche Philosophie letale, der keineswegs betroffen ist durch die Widerlegung des Psychologismus der reinen apophantische Logik und paralleler Psychologimus in der formalen Axiologie und Praktik.

Der traditionellen Transzendentalphilosophie fehlt es zwar nicht an einem argumentierenden Antipsychologismus, aber über alle natürlich nicht genug tiefgrundende Einwände sahen betreglicherweise diejenigen hinweg, die der Evidenz folgten, dass eine Wissenschaft vom Transzendentalen selbstverständlich auf die Bewusstseinserfahrung zurückgehen und auf diesem Boden in wirklich deskriptiver analytischer und eidetischer Arbeit eine prinzipielle Klärung aller Vernunft in ihren Sondergestalten leisten muss. Auf diesem Weg lag, wenn man ihn nur in radikaler Konsequenz verfolgt hätte, die Ausbildung einer rein eidetischen Phänomenologie. Diese hatte selbst vor der Erkenntnis der Notwendigkeit einer prinzipiellen Scheidung zwischen psychologischer und transzendentaler Phänomenologie... mindestens implizit die Hauptarbeit erledigt, obschon die wirklich sinnvolle Lösung erst nach dieser Scheidung eintreten konnte. Demgegenüber gerieten die Antipsychologisten, da sie aus Angst vor dem Psychologismus der systematischen und universales Bewusstseinsforschung auswichen und eine solche den Psychologen zuschoben, in ein leerlaufendes formalistisches Begriffsunterscheiden und Argumentieren, das dem Geist echter WissenschaFTLichkeit zuwider und wenig Frucht bringen konnte.

Eine endgültige Klärung des eigentlichen Sinnes wie der Transzendentalphilosophie, so des transzendentalen Psychologismus und dessen endgültige Überwindung, war erst möglich durch die Ausbildung der doppelten Idee einer eidetischen Phänomenologie und durch zugehörige radikale Besinnungen der Art wie sie von uns vorhin dargestellt worden waren." Hua LX, 345-346.

"Das Durchschauen dieser Parallele zwischen immanenter und apriorischer Psychologie (psychologischer Phänomenologie) und transzendentaler Phänomenologie und die Nachweisung einer Wesensnotwendigkeit ist die prinzipiell letzte Aufkläring des Problems des transzendentalen Psychologismus und zugleich seine Lösung." Hua XVII, 225. 
que tais manifestações sempre aparecem no contexto do desenvolvimento da via para a redução através da psicologia e, inclusive, que todas as abordagens husserlianas do tema do psicologismo em geral agora aparecem em tal contexto. Isto não é de modo algum casual, mas obedece à existência de uma estreita relação sistemática entre ambas as doutrinas.

\subsection{A compreensão última do psicologismo transcendental}

A crítica do psicologismo não pode meramente almejar a sua refutação, mas a sua superação (item 5): Ora, a superação definitiva do psicologismo só pode ser alcançada se o psicologismo for compreendido nas suas raízes últimas. Husserl teve sempre a convicção de que o psicologismo não é um mero erro, mas possui um nụ́cleo de verdade. Já nas Investigações Lógicas ele não pretendia ser tão somente um antipsicologista, mas realizar a mediação entre psicologismo e antipsicologismo. ${ }^{50}$ Naquele momento, ele percebia com clareza que os legítimos direitos do psicologismo estão vinculados à sua consideração da dimensão subjetiva. Ora, somente depois da virada transcendental Husserl é capaz de perceber o núcleo de verdade na doutrina psicologista: ela se encontra na sua "motivação transcendental" ${ }^{51} \mathrm{O}$ psicologismo se funda na observação, basicamente correta, de que todo ser se constitui na consciência. Por esta razão, só após a virada transcendental Husserl é capaz de perceber corretamente o núcleo transcendental do psicologismo. ${ }^{52}$

Mas o psicologismo não repousa meramente numa motivação transcendental, senão numa autêntica evidência. ${ }^{53}$ Ele exige, corretamente, que a epistemologia repouse em última instância sobre um fundamento descritivo.

"Die Phänomenologie bedeutet eben auch für die Psychologie eine prinzipielle Neugestaltung. Demnach gehört der bei weitem größten Teil ihrer Forschungen in eine apriorische und reine (d.h. hier, von allem Psychophysischen freigehaltene) intentionale Psychologie. Es ist dieselbe, von der wir schon wiederholt angedeutet haben, dass sie durch Verwandlung der natürlichen Einstellung in die transzendentale eine "kopernikanische Umwendung" zulässt, in der sie den neuen Sinn einer völlig radikalen transzendentalen Weltbetrachtung annimmt und allen phänomenologisch-psychologischen Analysen einprägt. Ersts dieser neue Sinn ist es, der sie alle transzendental-philosophisch verwertbar macht und sogar sie einer transzendentalen "Metaphysik" einordnet. Eben hierin liegt die letzte Aufklärung und Überwindung des transzendentalen Psychologismus, der die ganze neuzeitliche Philosophie beirrt und gelähmt hat". Hua I, 170-171. (Grifos meus.)

50 Hua XVIII, 6-7.

51 Hua IX, 42, 330-331.

52 A partir de 1923-1924 Husserl tenta oferecer não só uma introdução sistemática, mas também histórica à fenomenologia transcendental. É em tal contexto que começa a desenvolver a tese do telos transcendental da filosofia moderna, aprofundando a sua compreensão deste periodo. Vide Hua VII.

${ }^{53}$ Hua IX, 344 sgs. 
O psicologismo compreende, pois, ainda que confusamente, que a sua aspiração transcendental só pode ser satisfeita por uma fenomenologia. Ora, se o psicologismo repousa sobre uma verdadeira evidência, ele não pode ser superado "argumentativamente", mas tão-somente de um modo descritivointuitivo. A redução refuta o psicologismo porque ela opera a abertura de um autêntico campo de experiência, a experiência transcendental.

Se consideramos o que foi dito até agora, percebemos que a doutrina exposta, ainda que desenvolvida em 1927, era, a princípio, possível a partir de 1906. Tomando por base esta consideração, a pergunta inevitável é: por que então Husserl julga ser capaz de compreender definitivamente o psicologismo apenas em 1927? Qual é o elemento novo, que permite esta compreensão definitiva em 1927 e que, obviamente, ainda não estava presente em 1906? A resposta reza: segundo Husserl, o psicologismo repousa, em última instância, na perceção da identidade (e ignorância da diferença) da subjetividade psicológica e da subjetividade transcendental. Tal identidade, porém, só pode ser percebida após o pleno desenvolvimento do programa da psicologia pura.

Com efeito, não é outra coisa senão o pleno desenvolvimento da psicologia pura que, em 1927, faz passar a primeiro plano uma ideia já insinuada, mas não desenvolvida em 1906, de que existe um absoluto paralelo entre a subjetividade psicológica e a transcendental. Este "paralelo" se funda, em última instância, na identidade e diferença entre ambas as subjetividades, uma identidade e diferença que remete à teoria do "paradoxo da subjetividade". ${ }^{54}$ Ora, se a identidade e diferença de subjetividade psicológica e transcendental é a ratio essendi do paralelo entre ambas, que funda e dá sentido à própria ideia de um caminho para a segunda a partir da primeira, a psicologia fenomenológica é a respetiva ratio cognoscendi.

Se tudo o que foi afirmado até aqui é certo, então chegamos à seguinte conclusão, a qual não faz senão explicitar o que já está sugerido no percurso efetuado: o pleno desenvolvimento da psicologia pura é uma condição necessária da compreensão última e definitiva do psicologismo transcendental.

\subsection{A superação final e definitiva do psicologismo transcendental}

A redução é tanto o meio de alcançar a subjetividade transcendental quanto o meio de superar o psicologismo. ${ }^{55}$ Mas seria a redução enquanto tal capaz de superar plena e definitivamente o psicologismo? Se, como indicamos, a superação definitiva do psicologismo só é possível sobre a base da

\footnotetext{
${ }^{54}$ Hua IX, 330-331; Hua VI, 182 sgs.

${ }^{55}$ Hua IX, 315, 345-346. Ver item 5.
} 
sua compreensão última e esta pressupõe o pleno desenvolvimento da psicologia pura, então é previsível que, enquanto o desenvolvimento da psicologia pura possibilita uma via específica à filosofia transcendental, esta via deve ter um papel especial em uma superação definitiva. Digamos, então, que a superação definitiva do psicologismo pressupõe,

a. tanto o desenvolvimento da psicologia pura,

b. quanto a via para a redução transcendental que se torna possível através de tal desenvolvimento.

O pleno esclarecimento e a eventual prova da dupla tese proposta exige um complexo desenvolvimento que, no que segue, procuraremos efetuar em passos sucessivos.

Diferenciamos várias etapas tanto na ideia de psicologia quanto na via para a fenomenologia transcendental através dela. Por tal motivo, é claro que não podemos formular nossa tese falando sem mais de "psicologia pura" e "via para a fenomenologia transcendental através da psicologia", mas devemos referi-la especificamente ao pleno desenvolvimento da psicologia pura alcançado em 1927 e a forma que, sobre tal bașe, adquire a respetiva via. Não obstante, para evitar permanentes repetições, no que segue falaremos muitas vezes sem mais de "psicologia pura" e "caminho através da psicologia", ainda que, como se segue do que foi dito, estejamos nos referindo sempre, salvo aviso em contrário, à forma que estes assumem a partir de 1927.

Além disso, quando expomos a evolução da ideia de psicologia pura e da via através da mesma, deixamos deliberadamente fora de consideração a relação que este desenvolvimento mantém com o desenvolvimento da crítica ao psicologismo. É esta relação que dẹve ser clarificada agora. Tal clarificação supõe estabelecer uma resposta a trệs perguntas básicas:

a. Quais são as condições mínimas para que se possa colocar o problema do psicologismo transcendental?

b. Quais são as condições necessárias para que o mesmo possa ser reconhecido como tal?

c. Quais são as condições necessárias para que seja possível uma superação última e definitiva do mesmo?

Qué uma de essas condições é a sua própria compreensão última e definitiva, já foi adequadamente elucidado.

a. Husserl usa as expressões "filosofia transcendental" e "psicologia fenomenológica" em dois sentidos, um lato e um preciso. ${ }^{56}$ Existe uma pri- 
meira formulação do problema transcendental e da ideia de psicologia que já tem lugar em Descartes e, em particular, em Locke, a qual, porém, não desenvolve consequentemente nenhuma das duas. A origem do psicologismo transcendental se encontra neste primeiro vislumbre de filosofia transcendental derivado da assunção do princípio de imanência. Incorre-se no psicologismo transcendental (neste sentido) quando, partindo do princípio de imanência, se coloca a pergunta pela "constituição". ${ }^{57}$ Além do mais, se vislumbra o problema de uma psicologia fenomenológica quando, sobre a base do princípio anterior, se pergunta por uma esfera específica de experiência psicológica onde a questão constitutiva é abordada de modo descritivo. ${ }^{58}$ Por conseguinte, devemos dizer que o psicologismo transcendental tem a sua origem em Descartes e Locke, nos quais, não obstante, ainda que existam vislumbres da filosofia transcendental e da psicologia pura, nenhuma delas é desenvolvida de forma consequente. Portanto, um desenvolvimento consequente do problema transcendental e/ou de uma psicologia pura não são condições para que se possa colocar o problema do psicologismo transcendental.

b. A segunda pergunta já foi, na verdade, respondida num outro contexto..$^{59} \mathrm{O}$ psicologismo transcendental só pode ser reconhecido como tal quando se efetua a correta formulação do problema transcendental. Isto só é possível após a descoberta da redução. ${ }^{60}$ Disto se segue: o pleno desenvolvimento da psicologia fenomenológica não é condição necessária para que o problema do psicologismo transcendental seja reconhecido como tal.

c. No que diz respeito à terceira pergunta colocada, há não meramente uma, senão duas condições para a superação definitiva do psicologismo. A primeira é o pleno desenvolvimento da psicologia pura, a segunda é o caminho a redução que nela se funda. Com o primeiro nos ocuparemos no próximo item, com o segundo, no seguinte.

\subsubsection{A superação definitiva do psicologismo transcendental e a psico- logia fenomenológica}

Se o pleno desenvolvimento do programa de uma psicologia fenomenológica não é nem condição necessária para a colocação do problema do psicologismo transcendental, nem para seu reconhecimento, não obstante, ele é uma condição necessária da sua superação última.

\footnotetext{
${ }^{57}$ Hua IX, 330.

${ }^{58}$ Hua XVII, 137 e 225 sgs.; Hua XXV, 118, 139-140.

59 Ver item 5.

${ }^{60}$ Hua XVII, 224.
} 
A pergunta que orientará nossa exposição é a seguinte: por que Husserl está tão seguro, a partir de 1927, de ter alcançado a superação plena do psicologismo transcendental? Parte da resposta, já·a sabemos: porque crê tê-lo definitivamente compreendido. O restante da resposta, que agora abordamos, é: por que nessa compreensão lhe foi conferida sua forma última. Uma superação definitiva do psicologismo só pode ser alcançada quando o próprio psicologismo alcança sua forma última e isto só é possível através do pleno desenvolvimento da psicologia pura.

Explicitemos a linha argumentativa que é simplesmente pressuposta por Husserl:

a. A forma do psicologismo depende da forma da psicologia.

b. Uma superação definitiva do psicologismo supõe não meramente uma ideia definitiva da filosofia transcendental, mas também uma ideia definitiva da psicologia.

c. A ideia definitiva da psicologia só é alcançada através do desenvolvimento da psicologia pura.

d. Portanto, somente o pleno desenvolvimento da psicologia pura torna possivel a forma definitiva do psicologismo.

e. Em consequência, a superação definitiva do psicologismo supõe o pleno desenvolvimento do programa de uma psicologia pura.

Existem neste resultado vários aspetos que, nụma primeira formulação, como a que oferecemos, podem ser passados por alto e; por tanto, é conveniente explicitar. A psicologia fenomenológica torna possível uma nova forma de psicologismo que, sem ela, é absolutamente impensável. Esta forma de psicologismo não é uma forma de psicologismo entre outras, senão a forma definitiva além da qual já nenhuma outra é possível. Isto acontece porque a psicologia pura conduz o paralelo entre a subjetividade psicológica e a transcendental à sua expressão mais radical, ou seja, à perfeita coincidência do conteúdo de ambas, de modo tal que só resta entre elas a distinção puramente numérica (distinção numérica que, por outro lado, é em si mesma extremamente problemática, já que Husserl também nos diz que ambas subjetividades são idênticas, ainda que diferentes!). ${ }^{6 !}$

Até agora temos ressaltado que a forma última do psicologismo supõe a forma última da psicologia e esta só é alcançada na psicologia fenomenológica. A psicologia fenomenológica, porém, só é possível como uma consequência da fenomenologia transcendental e a pressupõe. Portanto, devemos 
aprofundar a nossa análise da forma última do psicologismo para situá-la, não mais em relação à psicologia pura, mas à própria fenomenologia transcendental.

Somente a psicologia fenomenológica é capaz de efetuar a análise intencional no sentido pleno, isto é, uma consideração propriamente constitutiva (na esfera psicológica). É por isso, e só por isso, que se pode colocar com embasamento a pergunta sobre se não caberá à psicologia fenomenológica ser o lugar da clarificação da questão transcendental, ou seja, justamente, o perigo de uma forma última e definitiva de psicologismo. ${ }^{62}$ Só a fenomenologia transcendental pode superar o psicologismo transcendental de modo definitivo, dado que:

a. a superação definitiva do psicologismo transcendental supõe o pleno desenvolvimento da psicologia fenomenológica.

b. mas só a partir da fenomenologia transcendental este pleno desenvolvimento é possivel,

c. dado que só a partir dela é possível uma análise constitutiva plena,

d. a qual é ulteriormente também desenvolvida no nível puramente psicológico.

e. Ora, dado que psicologismo transcendental em sua versão definitiva só e possível após a psicologia pura,

f. a totalidade do percurso anterior leva, então, à conclusão de que só a fenomenologia transcend'ental pode superar o psicologismo de modo absoluto, porque só ela é capaz de dar a ele sua forma última.

Nas considerações efetuadas tem sido implicitamente afirmado que há não apenas diferentes formas de psicologismo, o que é óbvio, mas também diferentes formas de "psicologismo transcendental". Procuremos distinguir essas últimas. Já que a forma do psicologismo depende da forma da psicologia, ordenemos as formas de psicologismo transcendental tomando como fio condutor o tipo de psicologia em questão em cada caso. ${ }^{63}$

a. Existe um psicologismo transcendental que se funda numa psicologia científico-natural e, em última instância, numa psicofísica. Esta forma de psicologismo transcendental, que também pode ser (e foi) denominada " "idealismo fisiológico", é extremamente comum na filosofia alemã da segunda metade do século XIX.

62 Hua XVII, 223; Hua LX, 335.

63. Ver item 6.2. 
b. Existe, por outro lado, uma forma de psicologismo transcendental que apela para uma experiência interna específica e se apoia numa psicologia que eleva a aspiração de ser plenamente descritiva. $O$ empirismo inglês é um claro exemplo desta espécie.

c. Existe, assim mesmo, uma forma de psicologismo transcendental que se baseia numa psicologia não só descritiva, mas também intencional, ainda que, não obstante, não possa se dizer que ela rompa plenamente com o naturalismo. Nesta direção vão as críticas de Husserl a Brentano e a Meinong.

d. Existe, ainda, uma forma de psicologismo transcendental que se funda numa psicologia descritiva que não apenas efetua análise intencional, senão que aspira a ser plenamente fenomenológica e, não obstante, ou não considera necessária a redução, ou a reinterpreta de modo inovador. Neste grupo contam-se Lipps e Pfander, que acompanham inicialmente com entusiasmo a nova fenomenologia e são decisivos na criação de um "movimento fenomenológico" propriamente dito, que transcende os limites da pessoa de Husserl.

e. Existe, finalmente, uma forma de psicologismo transcendental, a forma última e definitiva, que só é possível a partir da fenomenologia transcendental. Dito de outro modo, o psicologismo transcendental "refinado" não é uma possibilidade que alguém tenha efetivamente realizado entre os contemporâneos de Husserl, senão um perigo do qual Husserl adverte a seus discípulos e a si mesmo.

Distinguir com clareza a noção genérica de psicologismo transcendental (e eventualmente as suas possíveis variações) da noção extremamente específica de um psicologismo transcendental refinado que Husserl elabora em torno do ano 1927, é imprescindível tanto para o estabelecimento da peculiaridade da posição que Husserl assume a partir de esse momento, como para a compreensão do desenvolvimento do seu pensamento a partir de 1933 . $^{64}$

A relação entre fenomenologia e psicologia se opera em duas direções e é essencial a ambas. Por tal razão, o problema do psicologismo não é só, como Husserl muitas vezes sugere, um problema fundamental da filosofia em geral, senão, mais concretamente, um problema fundamental da própria fenomenologia. Para a fenomenologia, o psicologismo é um perigo que ela alberga em seu seio è que, portanto, deve permanentemente combater. O problema do psicologismo não é um problema dos Prolegômenos, como Husserl ingenuamente pensa em 1900, mas um problema interno à fenomenologia e que a acompanha como sua sombra, e isto necessariamente porque ela, por um lado, ao frutificar a psicologia o alimenta e, por outro, não obstante, tem que com- 
batê-lo para assegurar o seu próprio direito à existência. Este paradoxo, como Husserl gostaria de o chamar, não é um paradoxo qualquer, mas um paradoxo que diz algo de essencial com respeito à fenomenologia mesma. A origem de tal paradoxo está no fato de que a fenomenologia compartilha o princípio de. imanência com o psicologismo que combate, ainda que, através da redução, o reformule. De todo modo, a própria redução que o reformula, por isso mesmo, o pressupõe. Dito de outra forma, a fenomenologia transcendental traz em seu seio um problema que poderia ser resolvido por outros meios, meios que, porém, implicariam ábandonar o próprio projeto.

\subsubsection{A superação definitiva do psicologismo transcendental e a via à redução através da psicologia}

O problema da superação do psicologismo transcendental já se coloca com a introdução da ideia de redução enquanto tal e, por consequência, é absolutamente independente do desenvolvimento da noção de vias para a mesma. A pergunta é, não obstante, como a ideia de vias para a redução retroage no problema de uma superação do psicologismo transcendental. Quaïs são as novidades que se colocam com respeito a uma superação do psicologismo transcendental por meio da redução, quando já não temos mais "a" redução, mas diversas vias para a mesma? A nossa tese a respeito, anunciada no item 7.2., diz: o psicologismo transcendental em sua forma definitiva só pode ser superado através da redução pela via da psicologia no modo em que a mesma é concebida em 1927.

\subsubsection{As vias para a redução e a superação do psicologismo trans- cendental}

Se a temática das vias na redução tem sido extensamente discutida pela crítica, a pergunta referente à relação da crítica do psicologismo (em particulár do psicologismo transcendental) e as vias para a redução não foi abordada. ${ }^{65} \mathrm{Assim}$, neste item devemos expor a nova pergunta de como as vias para a redução se comportam em relação a uma superação definitiva do psicologismo transcendental e, mais concretamente, se para isto todas são igualmente eficientes.

No que segue defenderemos duas teses, uma mais geral, outra mais especifica:

a. A via através da psicologia fenomenológica tem uma vantagem decisiva na superação definitiva do psicologismo e, neste sentido, apresenta uma certa prioridade com respeito às restantes. 
b. A via através da psicologia fenomenológica é absolutamente necessária para a superação do psicologismo transcendental na sua versão definitiva.

Essas duas teses, ainda que vinculadas entre si, são essencialmente diversas e com certeza provocarão diferentes reações no leitor. Enquanto a primeira pode esperar ampla acolhida, a segunda, muito provavelmente, enfrentará uma rejeição radical. Husserl não teria reagido diferentemente, ou melhor dito, não reagiu. Em uma importante passagem do Gibson Konvolut, Husserl confirma expressamente nossa primeira tese, não obstante, observa não menos expressamente que isto não pode significar prescindir do "procedimento direto" ${ }^{66}$ Não desconhecemos, pois, que Husserl já abordou de modo explícito a pergunta que colocamos e a respondeu de modo negativo. Não obstante, insistimos na nossa tese com base em argumentos que exporemos. De toda forma, convém não passar por alto que já a primeira tese, não menos que a própria pergunta a qual ela responde, faz uma contribuição nada desprezível no contexto da questão referente às vantagens e desvantagens da cada uma das vias.

Comecemos por precisar nossas teses e evitar alguns equívocos. A questão das vantagens da via para a redução através da psicologia deve ser cuidadosamente distinguida da questão dos motivos que levam Husserl a propô-la. Não há dúvidas de que quando, em 1923-1924, Husserl introduz a via através da psicologia o faz para corrigir as insuficiências do caminho cartesiano com respeito a uma tematização da temporalidade imanente e da intersubjetividade e não para dar uma resposta ao problema do psicologismo transcendental. Mais que isso, e coerente com o posto: quando Husserl introduz em 1923-1924 a via através da psicologia não possui ainda a ideia de uma superação última e definitiva do psicologismo transcendental e nem sequer a ideia de uma forma última e definitiva do mesmo. É possível, pois, desenvolver a ideia de uma via particular através da psicologia sem situá-lả em relação com o tema do psicologismo transcendental..$^{67}$

Por outro lado, convém não perder de vista que a formulação precisa de nossa tese é umà condição necessária da sua plausibilidade. A nossa tese não se refere à relação entre a via através da psicologia e o psicologismo transcendental em geral. Sem dúvida, também as outras vias são capazes de efetuar uma refutação do psicologismo transcendental em geral, ainda que não seja uma questão óbvia nem secundária mostrar concretamente como e por que. Nossa tese se refere especificamente à relação entre via através da psicologia pura, na sua forma "última e definitiva", e o psicologismo transcendental, também na sua

${ }^{66} \mathrm{Hua}$ III//, 650.

${ }^{67}$ Como já indicado na introdução, este tipo de situação impede uma exposição simplesmente paralela da evolução dos temas mencionados. 
forma "última e definitiva", ideias que só aparecem a partir de 1927. Ambas as questões, por outro lado, estão estreitamente ligadas: o fato de que Husserl elabore a ideia de uma forma última e definitiva do psicologismo, ao mesmo tempo em que desenvolve o programa da psicologia pura, não é casual, como tampouco o é que, junto à perceção desta forma, ele reelabore a via através da psicologia.

\subsubsection{Argumentos para provar a tese de que o psicologismo trans- cendental refinado só pode ser definitivamente superado na via através da psicologia fenomenológica}

\subsection{Argumento direto}

Só o desenvolvimento da psicologia pura torna possível uma via para a redução através da mesma, pois só ela oferece o pressuposto dessa via, que reside justamente na plena coincidência de ambas as subjetividades, o que apenas através da mencionada psicologia pode ser manifesto. ${ }^{68}$ Ora, característico do caminho através da psicologia é o fato de que a redução se opera em dois passos, sendo que se diferencia com clareza e de princípio entre uma redução psicológico-fenomenológica e uma redução fenomenológico-transcendental. Assim colocado, se a superação do psicologismo em geral deve ser, e só pode ser, efetuada pela redução, a superação definitiva do psicologismo transcendental, ou seja, a superação do psicologismo transcendental na sua versão definitiva, só é possível mediante a dupla redução, isto é, em dois passos, de modo tal que a diferença entre as duas subjetividades, a psicológica e a transcendental, é manifesta de modo evidente. Em nenhuma das outras vias isto acontece, senão que são sempre necessárias precisões e explicitações ulteriores que, em definitivo, terminam remetendo à via através da psicologia.

Podemos argumentar o nosso resultado de outra forma. O que é reduzido na redução é o mundo. Não obstante, a esfera das "autênticas decisões" é propriamente a subjetividade. ${ }^{69}$ Para evidenciar isto se pode citar as inúmeras observações de Husserl em relação a Descartes no sentido de efetuar uma redução inconsequente que conserva o sujeito real como um "Endchen der Welt". Mas, como sabemos, é justamente Descartes o modelo sobre o qual Husserl se apoia para conceber a via cartesiana. Não é difícil conceber uma possibilidade correlativa no caso da via através do mundo da vida. A única via onde tal dificuldade não pode se colocar é justamente a via através da psicologia, já que ela tem expressamente seu foco na subjetividade. Há, pois, uma diferença essencial na redução operada na via através da psicologia e

\footnotetext{
${ }^{68}$ Ver item 7.1.

${ }^{69}$ Hua XXIX, 121.
} 
as outras. Só a via através da psicologia concentra explicitamente a redução naquilo que, afinal, é o realmente essencial, o ponto de maior dificuldade, e este é a subjetividade mesma. Mais ainda: só na via através da psicologia a redução transcendental se opera sobre uma subjetividade psicológica que foi primeiramente fixada em versão definitiva através da prévia redução psicológico-fenomenológica.

Podemos explicitar o que foi dito estabelecendo uma tripla distinção na execução da redução entre uma redução:

a. que é aplicada indiferenciadamente de forma universal;

b. uma redução que não só é universal, mas é aplicada especificamente à subjetividade e

c. uma redução que não só é universal e aplicada especificamente à subjetividade mas, além disso, a uma subjetividade em versão definitiva.

\subsection{Argumento fatual}

Concedido que é decisivo para o tratamento do tema do psicologismo diferenciar entre a redução como tal e a redução a partir da introdução das vias, não é menos decisivo distinguir quatro questões:

a. Como Husserl trata o problema do psicologismo transcendental antes de introduzir a noção de vias na redução?

b. Como Husserl trata o problema do psicologismo transcendental depois de introduzir a noção de vias na redução?

c. Como Husserl trata o mencionado problema quando ele desenvolve a via através da psicologia?

d. Como ele o trata quando desenvolve as restantes?

Já que anteriormente nos ocupamos da primeira pergunta, e já que a terceira e quarta são uma concretização da segunda, nos focaremos nas duas últimas.

Os meros fatos que não devem ser perdidos de vista são os seguintes:

a. A ideia de uma superação última e definitiva do psicologismo transcendental só aparece no pensamento de Husserl em 1927.

b. A partir de 1927 Husserl trata do problema do psicologismo transcendental, e inclusive, do psicologismo em geral, somente no contexto da via através da psicologia fenomenológica. Isto acontece não apenas nas Conferências de Amsterdam e no Artigo para a Enciclopédia Britânica, mas também em Lógica formal, lógica transcendental e Meditações Cartesianas. 
c. Husserl trata do problema do psicologismo transcendental refinado somente no contexto da via através da psicologia fenomenológica na versão de 1927 na qual se contrapõem explicitamente duas reduções, as distinguindo por princípio, não meramente por grau.

d. Pelo contrário, Husserl não trata do problema do psicologismo transcendental refinado quando ele aborda as outras vias. Tal é o caso em Meditações cartesianas, onde ele desenvolve a versão mais consequente da via cartesiana; tal é o caso, assim mesmo, em Lógica formal, lógica transcendental onde, se bem introduz a via ontológica através da lógica formal, considera o problema do psicologismo transcendental refinado também em relação com a psicologia fenomenológica. A pergunta óbvia é: por quê? ${ }^{70}$

\subsection{Argumento indireto}

Para nossa tese, pode-se argumentar de modo direto ou indireto. Pode-se evidenciar o que acontece quando a dupla redução é efetuada explicitamente; pode-se também mostrar o que acontece quando este não é o caso. Esta é justamente a situação que se apresenta em Ideias I em que Husserl, como se sabe, segue a chamada via cartesiana. Para o nosso tema é importante observar que a ideia de psicologia pura que, como vimos, começa a despontar em 1906-1907, desempenha um papel central, ainda que implícito, em 1913. A consequência desta situação são problemas e confusões com as quais desde então Husserl e seus intérpretes tiveram que lutar. O ponto principal é que o modo de exposição de Ideias I forneceu as bases para a crítica de uma recaída no psicologismo, a qual foi arduamente combatida por Fink em seu famoso Informe. Mas, apesar de toda competência e habilidade argumentativa de Fink, deve-se dizer que a dificuldade não está no leitor, mas no próprio texto, e isto por uma razão sistematicamente relevante.

Para esclarecer a totalidade da questão, comecemos com uma consideração geral. A partir de Kern, e por sua influência, se pressupõe que o descobrimento da redução coincide sem mais com a introdụção da via cartesiana, sendo que posteriormente outras vias vão sendo adicionadas. A consequência de tal ponto de partida é que repetidamente se tem que corrigir retrospetivamente as próprias afirmações, por exemplo, chamando a atenção de que se em $A$ Ideia da fenomenologia Husserl percorre a via cartesiana, não obstante, já percebe a possibilidade de uma via através das ciências particulares. Esses

${ }^{70}$ Por motivos que ainda haverão de ser indicados, a șituação em Crise merece uma consideração diferenciada 
ajustes retrospetivos, que tendem a se multiplicar de forma exasperante, poderiam ser evitados se fosse percebido que o que é inadequado é o esquema geral pelo qual se pressupõe que Husserl primeiro introduz $a, \operatorname{logo} b$, logo c. A situação que efetivamente se apresenta é melhor descrita se, em vez de partir da ideia de uma simples sucessão, dissermos que a redução, nas suas primeiras formulações, não contém claramente uma via, mas possui de modo indiferenciado a possibilidade delas, de forma tal que as mesmas só vão se perfilando na sua especificidade correlativiamente. Segundo este ponto de vista, em vez de identificar a introdução da redução com a introdução da via cartesiana, deveríamos dizer que a via cartesiana só se delineia como tal na medida em que se a delimita frente a outras. Em realidade, é esse o sentido último da tese de que a realização plena da via cartesiana se encontra nas Meditações cartesianas.

Com o dito estabelecemos um princípio geral para uma discussão proficua das relações entre as vias para a redução, sendo que no presente momento nos interessa aplicar o mesmo só ao caso concreto da via através da psicologia. A forma específica que assume esta via está em estreita relação tanto com a forma que assume a via cartesiana, quanto com a forma que assume a via através da ontologia e, em particular, através da ontologia do mundo da vida. Neste momento nos ocuparemos com a primeira relação; no item 9, com a segunda.

Como se sabe, em Ideias I, logo após o anúncio explícito da efetuação da redução, Husserl retorna ao sujeito psicológico, dado, pois, na atitude natural, e constrói a análise posterior sobre a base dos resultados da consideração intencional do referido sujeito. Se olharmos a situação de Ideias I retrospetivamente, a partir da perspetiva de 1923-1924, diríamos que esta obra se serve de fato da ideia de uma psicologia pura e, inclusive, de uma via através dela. Com efeito, não se trata de outra coisa senão de facilitar a consideração constitutiva partindo da análise da subjetividade psicológica para logo usufruir dos seus resultados no plano transcendental. Isto supõe, obviamente, o princípio de um absoluto paralelismo. Mas se é isto que dá sentido ao procedimento aplicado por Husserl, este, não obstante, não tematiza em 1913 nem a ideia de uma psicologia pura, nem constrói sobre a sua base uma via específica. Em consequência, o que falta realmente em Ideias I, e produz o conjunto da confusão, é a clara posição e delimitação de duas reduções construídas uma sobre a base da outra. Ideias I executa de fato uma redução psicológico-fenomenológica e constrói a transcendental sobre sua base, mas não legitima tal proceder mediante uma doutrina explícita. Em suma, Ideias I proporciona um exemplo interessante do que acontece quando todas as distinções que indicamos não são efetuadas. A consequência é que a fenomenologia fica exposta à objeção de que, no final das contas, recai no psicologismo. Ora, não passemos por alto esta questão: só tem sentido dizer que Ideias I não está livre de todo psicolo- 
gismo se, ao mesmo tempo, se concede que este psicologismo é de um tipo extremamente particular, ou seja, um psicologismo transcendental refinado.

Uma confirmação de nossa análise se encontra no Gibson Konvolut. ${ }^{71}$ Lembremos que, a partir de 1925, Husserl lê novamente Ideias I e efetua uma série de anotações e reformulações com o objetivo de oferecer uma versão melhorada para a edição inglesa. Os textos que em particular nos interessam pertencem, certamente por razões não casuais, aos anos 1927-1929, e se dirigem a uma reformulação daquelas passagens problemáticas do texto original anteriormente mencionadas. Todas as correções almejam erradicar o equívoco produzido pela rutura repentina do procedimento transcendental e a surpreendente introdução da análise psicológica. Isto acontece mediante um explícito e detalhado tratamento da via através da psicologia, com destaque especial na dupla redução.

Paradoxalmente, como já indicamos, é justamente no Gibson Konvolut que Husserl observa, além de todas as reformulações e correções mencionadas, que se o caminho através da psicologia apresenta inegáveis vantagens no tratamento do psicologismo, não devemos, entretanto, renunciar às outras vias e, em particular, à via direta. Mas não seria este um forte indício de que Husserl percebe as implicações da posição adotada e retrocede frente a algumas consequências que, então, lhe aparecem excessivamente radicais? O motivo para o não abandono da via direta não é, certamente, o psicologismo transcendental refinado.

\subsection{Caraterísticas singulares da refutação do psicologismo na sua forma última e definitiva}

Neste item nos propomos a explicitar as características peculiares que assume a superação final e definitiva do psicologismo transcendental e que não são encontradas na superação do psicologismo transcendental em geral, ou do psicologismo mesmo. É óbvio que essas peculiaridades representam novidades com respeito aos modos anteriores do tratamento do tema e que, por esta razão, a análise proposta deve ser efetuada sob a forma de uma comparação. O resultado da mesma se deixa resumir em três pontualizações:

a. O psicologismo não só não pode ser refutado de um modo puramente argumentativo, como criam os Prolegômenos, mas tampouco de um modo descritivo, como cria o segundo volume das Investigações Lógicas. ${ }^{72}$

71 Hua III/II, 650 sgs.

72 Ver item 5. 
b. O psicologismo não é necessiariamente a consequência de uma psicologia científico-natural. ${ }^{73}$

c. Toda a diferença entre a subjetividade psicológica e a transcendental só pode radicar em que uma "existe" e a outra não.

a. Não é certo que o psicologismo necessariamente se apoie numa descrição falsa da subjetividade. O psicologismo pode se fundar numa descrição correta da subjetividade, isto é, plenamente "fenomenológica". Em consequência, nem o problema, nem, por conseguinte, sua solução, podem ser de natureza "descritiva". Mais ainda: não só é possível incorrer em psicologismo quando se descreve corretamente a subjetividade, mas é possível incorrer nele justamente porque se a descreve corretamente. A superação do psicologismo, em última instância, não consiste em apontar a um algo que antes não tinha sido percebido, mas simplesmente numa mudança decisiva de perspetiva.

b. O impacto dos Prolegômenos foi tão grande na filosofia alemã do começo do século XX que, a partir deles, se começa a pensar que o psicologismo, entendido como redução da filosofia à psicologia, é por si mẹsmo um mal que merece ser combatido. Pressuposto e subentendido fica o fato de que o psicologismo conduz ao relativismo. Ora, como já vimos, na argumentação da tese de que o psicologismo é um contrassenso, é uma premissa o fato de que se trata da psicologia científico-natural. Esta premissa, aparentemente, não precisa de maiores fundamentações: resulta óbvio que tornar a consciência dependente de relações causais conduz ao relativismo, dado que a cada diferente constituição de nosso ser corresponderiam diferentes disposições cognitivas. Todo este sistema de pressupostos, não obstante, deve ser revisto na hora em que explicitamente se aceita a possibilidade de uma psicologia que não é científico-natural, como é o caso da psicologia fenomenológica. Podemos supor neste caso, sem esclarecimentos e complementos ulteriores, que o psicologismo conduz ao relativismo?

Vejamos o problema de outro ponto de vista. Sabemos que, a partir de 1912, Husserl introduz o conceito de motivação e a ideia de umã causalidade não científico-natural..$^{74} \mathrm{O}$ conceito de motivação apresenta a curiosa situação de consistir em um conceito regional de aplicação transcendental. Quem atua por motivação não é só a consciência transcendental, mas também a psicológica. Se tal é o caso, então se seguem consequências para o conceito de evidência. A teoria da motivação assenta as bases da ideia de um comportamento racional e, no caso particular da evidência, de uma evidência racional. Basta 
comparar o tratamento deste tema a partir de 1912 com aquele a ele outorgado nas Investigações Lógicas para perceber a mudança radical que se operou. Husserl critica o conceito de evidência como sentimento nas Investigações Lógicas e introduz a noção de evidência racional, justamente porque tal sentimento, enquanto parte integrante da legalidade da natureza, seria por esta última determinado e, em consequência, teria uma relevância racional nula. Vale o mesmo para uma evidência psicológica "motivada"?

Mas é possível fazer uma objeção ao nosso percurso de ideias: se reduzimos ao mínimo possivel o conceito de sujeito psicológico, então pertence a ele pelo menos o conceito de "realidade". Um sujeito psicológico é por definição um sujeito "real". Aqui se encontram contidas várias ideias diferenciáveis.

c. Tomemos a refutação kantiana da prova ontológica da existência de deus como ponto de partida de uma análise da posição husserliana com respeito ao psicologismo transcendental refinado. A única diferença entre a subjetividade psicológica e a transcendental parece ser a de que uma existe e a outra não. Mas pode a existência enquanto tal ser um predicado determinante que, em última instância, dê satisfatoriamente conta do porquê uma subjetividade nos conduz ao relativismo e a outra não?

Não podemos esgotar os temas apontadòs nos limites deste artigo e, por isso, iremos nos ater agora a duas observações ulteriores:

a. Husserl identifica, sem mais, ser, existência e realidade. Um interessante ponto neste sentido é a duríssima e quase dogmática reação de Husserl frente à proposta de Fink de determinar o ser do sujeito transcendental como pré-ser (Vorsein). ${ }^{75}$ Husserl não ignora que seu assistente, em sua disciplina sistemática, leva a fenomenologia uma e outra vez aos seus limites. Além disso: não está Fink, mais uma vez, chamando incomodamente a atenção sobre uma questão já levantada por Heidegger em suas observações ao artigo da Enciclopédia Britânica de que a fenomenologia carece de uma determinação ontológica adequada do sujeito transcendental, seu objeto de estudo próprio e exclusivo? Certamente, uma fenomenologia consequente deve resistir à prioridade de questões ontológicas, mas não as deve integrar de algum modo? Acaso a identificação de ser e realidade não fica presa ao objetivismo positivista cuja superação representa em boa medida o sentido histórico de uma fenomenologia?

b. Não algo essencialmente diferente, mas no fundo simplesmente um outro aspeto da mesma questão, se põe de manifesto se atentamos à distinção entre atitude natural e naturalística, introduzida por Husserl justamente no

75 Hua Dokumente, II/I, 93 sgs. 
mesmo contexto das reflexões sobre a ontologia regional após Ideias I em que se coloca a noção de motivação como modo de causalidade psicológica específica. ${ }^{76}$ Parece claro que uma psicologia fenomenológica, ainda que supere toda apreensão naturalística da subjetividade, está presa na atitude natural enquanto pressupõe o ser dado desta subjetividade, ou seja, a considera no âmbito da tese do mundo. Mas onde se encontra em Husserl a consideração das consequências desta distinção para o problema do psicologismo?

\section{Intermezzo II: A relação positịa entre subjetividade psicológica e transcendental e o tema da auto constituição}

O tema do psicologismo concerne só ao aspecto negativo de um problema mais abrangente, a saber, aquele referente às relações entre a subjetividade psicológica e a transcendental. Por consequência, ele possui necessariamente um contraponto positivo. Não pode, pois, se tratar unicamente de distinguir do modo mais radical possível a subjetividade psicológica da transcendental, mas, mesmo assim, deve-se poder dar conta de como essas duas subjetividades, tão díspares entre si, não obstante, se vinculam.

A questão indicada não é nova nem é específica da fenomenologia husserliana. Ela já se coloca nós primórdịos da controvérsia psicologista. ${ }^{77}$ Já Bolzano se vê enfrentado por Exner com a interrogação de como é possível que um sujeito psicológico real seja capaz de apreender um objeto ideal irreal e, frente a tal questão decisiva, permanece sem uma resposta conclusiva. Situação similar será colocada na crítica de Kerry a Frege. O discípulo de Brentano acusa ao autor dos Fundamentos da aritmética de um "horror subjectivi", uma crítica à qual, muito provavelmente, Frege vai de encontro no prólogo das Leịs fundamentais da aritmética, onde, para mostrar que não luta contra "moinhos de vento" ("Windmühle"), analisa pormenorizadamente a posição de Erdmann. Junto a Bolzano e Frege não se pode deixar de lembrar de Hermann Cohen, que, por sua vez, com sua conceção lógico-objetivista da subjetividade transcendental, motivará seu discípulo, Paul Natorp, a reintroduzir a subjetividade "autêntica" no âmbito da filosofia transcendental mediante sua Psicologia geral.

Se, do contexto da discussão da filosofia alemã em torno do tema do psicologismo, nos dirigirmos agora a Husserl e à evolução da sua fenomenologia, então temos que dizer que já nas Investigações Lógicas ele procurava

${ }^{76}$ Hua IV, 188 sgs.

77 Cf. do autor: Platonismo e intencionalidade. A propósito de Bernhard Bolzano e Frege y Natorp: Platonismos, Antipsicologismos y teorias de la subjetividad. 
não meramente refutar o psicologismo por meio da afirmação das idealidades, senão também, explicitamente, abordar a questão da relação da subjetividade psicológica real a tal reino ideal. ${ }^{78} \mathrm{Com}$ a introdução da redução transcendental o referido problema não desaparecerá do pensamento de Husserl, mas adquiririrá uma nova forma. A partir de 1906 já não se tratará de dar conta da relação de uma subjetividade real a um objeto ideal, mas de dar conta da relação de uma subjetividade psicológica a uma transcendental.

Com esta colocação Husserl introduz uma novidade no contexto da controvérsia psicologista mencionada. Enquanto em 1900 o problema de Husserl se move no âmbito das exigências de Exner e Kerry a Bolzano e Frege respetivamente, a partir de 1906 Husserl, logo de criticar ferozmente em 1900 qualquer psicologia transcendental, redescobre o problema natorpiano, porém, numa variante nova. Já não se trata de vincular uma subjetividade autentica a um reino transcendental de puras valências lógico-objetivas, mas de dar conta da relação de uma subjetividade real a outra transcendental.

Ora, se o problema da relação positiva entre subjetividade psicológica e subjetividade transcendental já se coloca em princípio com o próprio descobrimento da redução transcendental, não é menos certo que, num primeiro momento, ele está, por assim dizer, ofuscado pela questão, mais urgente, de uma superação do psicologismo. Justamente por isso, é no momento em que tal questão chega ao seu clímax, ou seja, em 1927, que se opera uma mudança nos acentos que haverá de culminar em 1936. O clímax do problema do psicologismo - e justamente porque Husserl leva ao seu limite a identificação entre a subjetividade psicológica e a transcendental - muda a urgência sistemática da delimitação para a da integração.

A clarificação positiva das relações entre subjetividade psicológica e subjetividade transcendental remete ao problema da constituição ou, melhor, da autoconstituição da subjetividade. Ora, continuando o proceder genético-evolutivo que seguimos no Intermezzo anterior, convém diferenciar pelo menos três etapas claras a esse respeito no pensamento de Husserl.

a. O início da temática da constituição da subjetividade está dada no âmbito do desenvolvimento da ontologia regional a partir de 1912, em que, frente à teoria da constituição da coisa e do espaço, aparece o tema da constituição da alma e do sujeito espiritual. Temas centrais neste contexto são os referentes a kinestesias e ao corpo próprio.

b. Em torno de 1917 o problema da consciência do tempo imanente, que vem sendo desenvolvido desde 1905, ou seja, antes da redução, passa a se 
concentrar na teoria da constituição da subjetividade transcendental a partir do fluxo originário do presente vivo.

c. Finalmente, no marco da colaboração com Fink (1930), toma contorno no pensamento husserliano, como aspeto da "fenomenologia da fenomenologia", a questão da constituição do sujeito fenomenológico.

\section{Sexto momento: 1936. A identificação de psicologia fenomenológica e fenomenologia transcendental em Crise}

Existe uma intensa discussão, ainda hoje em curso, sobre o significado da última obra de Husserl e, em particular, sobre o modo em que ela deve ser interpretada em relação ao desenvolvimento anterior. Segundo uma opinião extremamente estendida, Crise representa uma mudança dramática, um abandono do projeto transcendental e uma virada à história e à facticidade sob a pressão irresistível da analítica do Dasein. Em tal contexto, se costuma citar, hoje já não sem contestação, uma famosa anotação de Husserl com respeito ao fim de um sono.

Curiosamente, nesta discussão toda se tem dedicado pouca atenção ao tratamento detalhado da crítica do psicologismo e, eventualmente, à relação em que a mesma se encontra com as posições defendidas anteriormente por Husserl. Talvez tenha sido decisivo para isto o fato de que o tema do psicologismo, à diferença daqueles da história e do mundo da vidà, não é um dos temas novos da obra. Mas, não obstante isso, ele não é um tema de Crise entre outros, senão um tema que oferece chaves hermenêuticas nada despreziveis para os efeitos de uma interpretação global da obra em questão.

Vimos que os inícios da fenomenologia estão vinculados aos intentos de delimitar fenomenologia e psicologia. ${ }^{79}$ Crise fecha este desenvolvimento com uma posição que, a princípio, não pode senão aparecer como estranha e paradoxal, enquanto ensina, de forma expressa, a tese da identidade entre psicologia fenomenológica e fenomenologia transcendental. O desenvolvimento consequente da psicologia fenomenológica, nos é dito agora, conduz por si mesmo à fenomenologia transcendental. Existe entre ambas as disciplinas, eventualmente e no melhor dos casos, uma diferença na consequência da execução: a psicologia fenomenológica não é senão um passo na direção da fenomenologia transcendental e, em seu consequente desenvolvimento, se dissolve de modo necessário nesta última. ${ }^{80}$ 
Ora, sabemos que a discussão das relações entre psicologia e fenomenologia se encontra em estreita relação com o problema do psicologismo. Sob tal ponto de vista é razoável pensar que, assim como os intentos de distinção entre psicologia e fenomenologia estiveram desde o começo marcados pela luta antipsicologista, a identificação final de ambas as disciplinas será interpretada como sinal de que, finalmente, na sua última obra, Husserl abandona tal luta ou, numa variante mais extrema, recai finalmente no psicologismo que durante toda sua vida tinha tão duramente condenado. Não obstante, e contra o que em um primeiro momento poder-se-ia pensar, são duas coisas absolutamente diferentes o fato de que Husserl culmine seu desenvolvimento numa identificação entre psicologia e fenomenologia e o fato de que Husserl tenha abandonado finalmente a luta psicologista e se tornado ele mesmo psicologista. Se, seguindo distinções que já efetuamos, entende-se por psicologismo um sinónimo de "relativismo", então, deve se dizer que Husserl é em Crise um crítico tão severo do relativismo como sempre o fora. A crítica do relativismo, ao qual Husserl agora se refere na maioria das vezes como "subjetivismo", é um ensinamento tão presente em Crise como nas obras anteriores:

Se a crítica do psicologismo, e mais ainda, a crítica do psicologismo transcendental não desapareceu de Crise, o que em verdade desapareceu é o problema do psicologismo transcendental refinado e a ideia correlativa de uma superação última e definitiva do mesmo. Existe em Crise uma notável ausência e ela radica no fato de que nesta obra Husserl nem sequer menciona o problema que tanto o preocupou a partir de 1927. Husserl desconsidera em Crise uma possibilidade que a própria evolução da fenomenologia o tinha conduzido a considerar e que só se poderia apresentar a partir do pleno desenvolvimento do projeto da psicologia pura. O que a posição de 1936 realmente significa só pode ser fixado no contexto do desenvolvimento husserliano e por referência ao período anterior ${ }^{81}$ e não se se aborda a mesma unicamente no âmbito de referências extrínsecas. $O$ conceito de um psicologismo transcendental refinado é um conceito sistemático imanente à fenomenologia transcendental, um construtor próprio que ela coloca para se compreender e que retira quando percebe que ele, em realidade, obsta esta compreensão.

Se simplificamos o desenvolvimento total de Husserl, poder-se-ia dizer que ele inicia sua fenomenologia com a distinção entre fenomenologia e psicologia e a culmina com sua identificação. Mas não é possivel entender Crise se se parte de tal esquema simplificado: é necessário introduzir o sistema de distinções que, laboriosamente, fomos estabelecendo ao acompanhar passo a passo o desenvolvimento do pensamento husserliano. Crise não opera, sem

81 Ver item 7. 
mais, a identificação de psicologia e fenomenologia, mas concretamente de psicologia fenomenológica e fenomenologia transcendental. É justamente este o ponto decisivo no qual se deu uma mudança com respeito à posição anterior.

A identificação de psicologia fenomenológica e fenomenologia transcendental e o abandono da ideia de um psicologismo transcendental definitivo são dois lados da mesma moeda. A verdadeira motivação na tenaz distinção entre psicologia fenomenológica e fenomenologia transcendental não era outra senão advertir sobre a possibilidade de uma variante do psicologismo extremamente refinada. Pelo contrário, fica compreendido que uma psicologia fenomenológica plenamente consequente não traz consigo tal perigo, então já não existe razão para delimitar esta da filosofia transcendental por um "abismo de sentido".

Mas com isto já antecipamos um ponto essencial que merece ser tratado com todo detalhe. Se, por um lado, Crise ensina a identidade da psicologia fenomenológica e da fenomenologia transcendental e, por outro, não menciona o problema do psicologismo transcendental refinado, tanto mais importante é observar que Crise mantém a ideia de um caminho à redução através da psicologia fenomenológica e o coloca em pé de igualdade com a grande novidade da obra, a via através do mundo da vida, e isto em um contexto em que a via cartesiana não é mencionada.

O que leva Husserl agora a abandonar a tese da possibilidade de um psicologismo transcendental refinado não é outra coisa que a tomada de consciência de que a mesma repousa numa compreensão errônea da própria essência dả psicologia, uma compreensão na qual se concede sentido, ainda que se a combata, à noção de uma psicologia "naturalista". O psicologismo só é possível sobre a base da atitude natural. É, ao invés, reconhecido que uma psicologia na atitude natural contém por princípio um contrasșenso, então perde toda sustentação a ideia de um psicologismo transcendental refinado. O psicologismo transcendental refinado só é possível quando a psicologia mesma não se autocompreende, ou seja, quando não reconhece seu caráter autenticamente transcendental.

O processo que chega a sua culminação em Crise consistiu não em que, finalmente, a fenomenologia transcendental se psicologizou, senão, muito pelo contrário, em que a psicologia se transcendentalizou. Não se trata de uma psicologização última da subjetividade transcendental, senão, pelo contrário, de uma última transcendentalização da subjetividade psicológica. Isto pode, à primeira vista, parecer um simples jogo de palavras, mas é, não obstante, a forma mais precisa de descrever o estado de coisas que nos é apresentado em 1936, quando não, o único modo de tornar um complexo movimento evolutivo internamente coerente. ${ }^{82}$ 
O ponto primário é que não se trata, em 1936, de que a fenomenologia simplesmente se reconhece então como psicologia, como se ela pudesse se apoiar num conceito de psicologia que simplesmente lhe fora dado e que pudesse ter sentido independentemente dela. As radicais afirmações que Husserl faz a respeito da psicologia em 1936 referem-se a uma psicologia que só tem sentido a partir da fenomenologia transcendental e que foi possibilitada por ela. O que é propriamente dito é: só a partir da fenomenologia transcendental e por meio dela é possível a autêntica psicologia.

Mas, poder-se-ia pensar, em tudo isso não há nada de propriamente novo. Afinal, acaso já não sabíamos desde as Investigações Lógicas que a fenomenologia fecundava a psicologia? E então? O que mudou? Por que, não obstante afirmando reiteradamente que a fenomenologia fecundava a psicologia, Husserl mantinha uma distinção de princípio entre ambas que abandona em 1936 ?

A partir de 1933, com a Conferência de Praga, ${ }^{83}$ que assenta as bases da obra final, se anuncia algo novo, algo que fica diluído em Crise como mais um elemento. A tese "inicial" de Husserl era, não esqueçamos, que a Crise da ciência europeia se fundava, ou melhor, era em última instância, uma Crise da psicologia. ${ }^{84} \mathrm{O}$ ponto decisivo em que se decide ou o afundamento na Crise, ou a saída da mesma, não é outro que a própria psicologia. Ora, isto significa, concretamente, que a luta contra o objetivismo que impregnou a cultura europeia na modernidade se decide no campo da psicologia, ou seja, só é possível mediante uma liberação da psicologia de todo resídúo objetivista. ${ }^{85}$

É no âmbito desta ideia diretriz que devemos entender como e por que Husserl altera a sua visão da psicologia, pois, em definitivo, é isto propriamente o que acontece. A atenção às consequências não nos pode levar a perder de vista as verdadeiras causas. Em última instância, a identificação de psicologia fenomenológica e fenomenologia transcendental, a mudança na doutrina da redução e, claro está, o próprio abandono da ideia de um psicologismo transcendental refinado, não são mais que derivações da mudança decisiva operada na própria compreensão da psicologia.

O sentido último da relação entre psicologia e fenomenologia não é de delimitação, mas de realização. O centro de interesse já não está, como a partir de 1923-1924, no fato de que a psicologia fenomenológica abre um caminho para a fenomenologia transcendental, mas no fato, não totalmente desconhecido naquele momento, de que a fenomenologia transcendental é propria-

\footnotetext{
${ }^{83}$ Hua XXIX, 103 sgs.

84 Hua XIX, 137.

${ }^{85}$ Hua VI, 215 sgs.
} 
mente a via para a plena realização da psicologia. ${ }^{86}$ Uma psicologia que supera plenamente o objetivismo, necessariamente se reconhece a si mesma como transcendental. ${ }^{87} \mathrm{O}$ sentido histórico da fenomenologia é agora, igualmente, possibilitar a autêntica filosofia e a autêntica psicologia, mas já não como duas coisas diversas, como acontece em 1927, mas como a mesma.

A superação definitiva de todo resto de objetivismo na psicologia só pode ser efetuada sob a forma de uma crítica radical do dualismo. ${ }^{88}$ Existem formas e graus diversos de objetivismo. Existe certamente um objetivismo que simplesmente nega o psíquico. Existe, não obstante, um objetivismo não menos perigoso que, por um lado, reconhece a especificidade do psíquico e, por outro, o pensa a partir do físico à medida que o concebe com base na ideia fundamental de um absoluto paralelo entre ambos. A crítica do objetivismo na

\section{Hua XXIX; 137.}

87 "Im Zug unserer Gesamtbetrachtung ist noch von besonderer Wichtigkeit, dass der ganze Sinn, in dem der Psychologe am Anfang eine rein deskritptive Psychologie forderte und der sich in Form der Phänomenologie zwar erfüllte, aber auch in eigentümlicher Weise total verwandelte. Erste war eine Wesenlehre der Seelen, der in der Welt als Realitäten verstreuten. In der konsequenten und reinen Ausgestaltung der Phänomenologie lernt der Psychologe aber verstehen, dass er selbst in dieser reinen Einstellung nicht mehr das in der Welt naiv seiende, sondern das absolute Ego ist, in welche die Welt- und Selbstapperzeption statthaben als der absolute Prozess, aus dem in rein innerer Vergemeinschaftung mit anderen die Welt ihren Seinsinn gewinnt. Danach verliert die rein phänomenologische Psychologie ihren Anfangsinn, den einer spezialen objektiven Wissenschaft. Sie verwandelt sich von selbst in die absolute Transzendentalphilosophie... Die am Anfang notwendige Trennung zwischen rein innenpsychologischer (phänomenologischer) und transzendentaler Einstellung hebt sich in dem sich zu einem höheren Selbstverständnis erhebenden Phänomenologie wieder auf. Wohlverstanden ist die phänomenologisch-psychologische Reduktion nur die noch nicht zum letzten Selbstvẹrständnis gekommene transzendentalen Reduktion. Durch diese Klärung ist nicht etwas ausgeschlossen, dass der Psychologe im Wechsel, wenn er im Wechsel der Einstellung die Ichsubjekte in der Welt vorfindet, die Einsichten der transzendentalen Phänomenologie doch als Mittel verwendet, objektiv wissenschaFTLich, nämlich über Menschen als raum-zeitlich in Körpern lokalisierte Subjekte empirisch-induktive Aussagen zu machen, so zu Zwecken der Psychophysik. Natürlich ist aber die Aufklärung dieser uneigentlichen Lokalisierung der Subjekte, -sowie des Scheines einer analogen Realität derselben wie der der Natur eine der grossen Aufaben der reinen Phänomenologie. Nach alldem will es mir scheinen, dass mit der Ausbildung der transzendentalen Phänomenologie das Ringen der Jahrhunderte um die wahre Methode, um den echten Zwecksinn einer Psychologie in ein entscheidendes Stadium gekommen ist. Unhaltbar geworden ist jetzt die Idee der Psychologie als einer Ergänzungswissenschaft zur Naturwissenschaft." (Hua XXIX, 136-137. Cf. Hua VI, 271). "Allerdings, ein ungeheurer Unterschied zeigt sich in dieser Aufweisung der echten Parallele zwischen Psychologie und Naturwissenschaft, ja zwischen Psychologie und jeder positiven Wissenschaft überhaupt. Der Psychologe, das rein Seelische suchend, in der absolut unausweichlichen Nötigung, alle reale Mitgeltungen ausser Spiel zu setzen, vollzieht Epoché, und sie dann, und wieder unvermeidlich, in schwieriger Besinnungen methodisch durchführend, befreit er sich von der Naivität, welche allem Weltleben und allen objektiven Weltwissenschaft unbewusst anhaftet." (Hua VI, 263-264). 
psicologia deve se efetuar concretamente sob a forma de uma crítica do dualismo e do paralelismo que este pressupõe..$^{89}$

A psicologia tradicional, reflexo do empirismo inglês, é a consequência da busca de um paralelo entre física e psicologia. O êxito da física é um fator decisivo para que outras ciências, inclusive a psicologia, pretendam seguir o seu modelo. Isto se expressa no conceito de experiência. $O$ intento de equiparar a psicologia à física e, ao mesmo tempo, diferenciá-la, conduz à elaboração da ideia de um dupla modalidade de experiência, interna e externa, constituída sobre o modelo da segunda e à qual, em última instância, subjaz uma ideia de experiência única ou unificada. Mas a ideia de um conceito único de experiência, ainda que essa experiência ofereça duas variantes, é um contrassenso dado que ele, em última instância, repousa sobre o pressuposto de um em si. $\mathrm{O}$ conceito de experiência psíquica, como ser dado de um certo objeto, ainda que um objeto diferente do físico, é insustentável. A oposição entre físico e psíquico não é a oposição de dois tipos de experiência, mas a diferença entre aquilo que subjaz na experiência e o próprio experimentar que se constitui como pólo intencional da mesma. Psíquico não pode querer dizer um tipo de objeto, mas só o correlato de todo objeto. De uma forma ou de outra, o dualismo sacrifica a especificidade do psíquico, perde de vista o seu caráter intencional irredutível, tenta pensar o que só pode ter o ser do para si, como um em si. ${ }^{90}$

O programa da psicologia fenomenológica tentou se opor ao dualismo e combater as deformações descritas. Mas teve sucesso? Se nos atemos tanto às análises particulares que Husserl desenvolve no marco da mesma, como às suas insistentes e precisas orientações metodológicas, a princípio a resposta só pode ser afirmativa. E, não obstante, todo o programa da psicologia fenomenológica esteve desde o inicio contaminado pelo dualismo à medida que fora pensado no âmbito da ontologia regional. ${ }^{91}$ Mais ainda, a própria ideia de ontologias regionais reintroduz no seio da fenomenologia uma conceção cheia de implicações que justamente a fenomenologia pretende combater.

$\mathrm{Na}$ ontologia regional, o mundo é pensado como composto de duas regiões, com certeza, radicalmente diferentes e, não obstante, num certo

89 Hua VI, 219 sgs.

${ }^{90}$ Hua XXIX, 122 sgs., 132 sgs.

91 Em um texto de Junho de 1912, que descreve o proceder de Ideias I, Husserl observa: "Naiv beginne ich mit der Gegenübersetzung von Tatsachenwahrheiten - eidetische... Ich steige so auf zur Parallelisierung von eidetischer Wissenschaft der Natur und vom Geist und darin von Phänomen." Hua III/2, 526. Comparar p. 528. Em 1936, Husserl escreve: "Aber nun ist an der Zeit, endgültig den Widersinn der ganzen Parallelstellung der Psychologie und der Naturwissenschaft herauszustellen..." Hua XXIX, 132-133. 
sentido, enquanto igualmente regiões do mundo, niveladas. $\mathrm{O}$ signo mais manifesto deste nivelamento é a teoria da dupla e correlativa abstração. ${ }^{22}$ Primeiramente devemos estabelecer o reino do puramente fisico e, para isso, abstrair de todo o psíquico; correlativamente, devemos estabelecer o reino do puramente psíquico e, para isso, abstrair de todo o fisico. Mas o que nesse simples esquema permanece oculto é o fato de que, em realidade, ambas as abstrações designam algo radicalmente diferente, e só de modo superficial podem ser consideradas como movimentos imediatamente correlatos. Na abstração do físico, o psíquico permanece absolutamente fora de consideração; na abstração do psíquico, pelo contrário, o físico permanece; ele não é simplesmente desconsiderado, mas conservado como correlato do ato intencional, no qual propriamente consiste o psíquico. ${ }^{93} \mathrm{~A}$ ideia de uma dupla abstração correlativa, que dava base ao nivelamento de física e psicologia puras como ontologias regionais, é extremamente problemática. Se observamos com cuidado vemos que, na realidade, esse problema já era apontado ao se assinalar que, enquanto o estabelecimento do físico puro era viável através de uma abstração, o correlato estabelecimento do psíquico puro exigia um tipo particularíssimo de abstração que é justamente o que, desde o começo, foi chamado redução psicológica.

Ora, o que Husserl abandona em 1936 é a ideia de uma redução psicológica específica diferente da transcendental. ${ }^{94} \mathrm{~A}$ redução psicológica, se é plena e consequentemente efetuada, deve por si mesma conduzir à transcendental. Uma redução psicológica que "permanece em si mesma", de modo tal que não se autocompreende de modo satisfatório, percebe corretamente uma tarefa que, não obstante, deixa sem resolver. A ideia de uma redução não-transcendental é problemática. ${ }^{95}$

Se se tem clareza sobre o que foi dito, então a totalidade da sistemática da fenomenologia transcendental exige uma reformulação. Em realidade, não podemos situar o fisico e o psíquico num mundo unitário, contraposto por igual à subjetividade transcendental, mas devemos pensar ambos como contendo uma assimetria essencial. É a compreensão dessa assimetria essencial entre físico e psíquico o que rompe de modo definitivo com todos os resquícios do dualismo e mostra que, o que em princípio parecia a ontologia regional do psíquico, a psicologia pura, consequentemente desenvolvida, isto é, sem tentações objetivistas, se identifica finalmente com a fenomenologia transcendental.

\footnotetext{
92 Ver item 6.1.4.

93 Hua XXIX, 133-134. Ver item 6.3.

${ }^{94}$ Hua VI, 255, 259.

95 Hua XXIX, 137.
} 
Se se concede tudo o que foi dito, e só então, é possível tornar transparentes afirmações que Husserl efetua em Crise de modo circunstancial e, talvez, sem o suficiente destaque da sua importância. Em 1906-1907, quando a ideia de uma psicologia pura foi concebida, ela era por si e sem mais uma psicologia eidética, motivo pelo qual ela aparece não poucas vezes sob a denominação "psicologia racional". Em 1912, quando a ideia da psicologia pura começa a ser desenvolvida no âmbito da ontologia regional, se insiste no fato de que ontologias regionais são ciências eidéticas não transcendentais. ${ }^{96}$ Quando em 1923-1924 se introduz a ideia de uma redução psicológica específica, chama-se a atenção ao fato de que sobre o resultado da mesma deve se operar uma redução eidética. A ideia de uma essência específica do psíquico faz pleno sentido no contexto da inclusão da psicologia pura na ontologia regional. Quando chegamos em 1936, porém, Husserl afirma em alto e bom tom que não há uma ciência eidética específica do psíquico, mas que ela não é outra coisa que a fenomenologia transcendental. ${ }^{97}$ Certamente, tal afirmação só pode ser efetuada por alguém que, mediante o desenvolvimento da ideia de uma psicologia pura, se vê conduzido a deslindar a mesma do projeto de ontologia regional, isto é, de a liberar de um último resíduo de dualismo que é o que conduz em definitivo à paralelização de psíquico e físico e, com isto, a naturalização da primeira.

É no contexto de ideias exposto, finalmente, que se torna compreensível uma grande ausência de Crise (ausência que bem poderia ser interpretada como signo da final "despedida do cartesianismo"), a saber, que Husserl não usa na sua última obra, e nem sequer menciona, à via cartesiana: Esta situação responde a uma essencial e profunda mudança sistemática que pode ser posta em relevo mediante uma comparação com o Gibson Konvolut. Se, nestes manuscritos, Husserl podia ainda insistir que a via através da psicologia não tornava prescindível a via direta ${ }^{98}$ agora tal afirmação perde o seu fundamento. Não há uma subjetividade transcendental diferente da psicológica que pudesse ser acessada de modo "imediato", ou seja, sem implicar um apelo à psicologia. A subjetividade transcendental não é outra coisa que o psíquico puro.

96 Ver item 6.3.1.

97 "In der Tat, für eine echte Psychologie und für die Exaktheit, welche die ihr eigenwesentlich ist, spielt die Transzendentalphilosophie die Rolle der apriorischen Wissenschaft, die sie in allen ihren wirklich psychologischen Erkenntnissen zu rekurrieren, deren apriorische Sturkturbegriffe sie für ihre weltliche Empirie zu verwerten hat." Hua VI, 263-264.

${ }^{98}$ Ver item 7.2.2.1. 


\section{Referências}

DRŪE, Hermann (1963). Edmund Husserls System der phänomenologischen Psychologie. Berlin: Walter de Gruyter.

FINK, Eugen (1933). Die phänomenologische Philosophie Edmund Husserl in der gegenwärtigen Kritik. Kant Studien, 35: 319-383.

FnK, Eugen (1988). VT Cartesianische Meditation. Teil 1: Die Idee einer transzendentalen Methodenlehre. Texte aus dem Nachlass Eugen Finks (1932) mit Anmerkungen und Beilagen aus dem Nachlass Edmund Husserls (1933/34). Hans Ebeling, Jann Holl \& Van Kerckhoven (ed.). Huserliana: Dokumente, vol. 2/1. Dordrecht: Kluwer Academic Publishers.

FINK, Eugen (1988). VI Cartesianische Meditation. Teil 2: Ergänzungsband. Texte aus dem Nachlass Eugen Finks (1932) mit Anmerkungen und Beilagen aus dem Nachlass Edmund Husserls (1933/34). Guy Van Kerckhoven (ed.). Huserliana: Dokumente, vol. 2/1. Dordrecht, Kluwer Academic Publishers.

GonzÁlez PorTa, Mario Ariel (1999). Los orígenes de la virada antipsicologista en Hussserl. (La reseña a Schröder de 1891 revisada). Themata, XXI:85-116

GonzÁlez Porta, Mario Ariel (2002-2003). Platonismo e intencionalidade A propósito de Bernhard Bolzano. Síntese (nova fase): Primeira parte: 29(94), 2002: 251-275; Segunda parte: 30(96), 2003: 85-106

GonzÁlez PORTA, Mario Ariel (2006). Frege y Natorp: Platonismos, Antipsicologismos y teorías de la subjetividad. O que nos faz pensar, 20: 163-184

GonzÁlez Porta, Mario Ariel (2010). Algunas consideraciones en torno a la distinción de tipos de psicologismo en Husserl. Cognitio, II(2): 279-302

HuSSERL, Edmund (1950). Cartesiamische Meditationen und Pariser Vorträge. S. Strasser (ed.). Husserliana, I. Haag, Martinus Nijhoff.

HusserL, Edmund (1950). Die Idee der Phänomenologie. Fünf Vorlesungen. Walter Biemel (ed.). Husserliana, II. Haag, Martinus Nijhoff.

HUSSERL, Edmund (1950-1952). Ideen zu einer reinen phänomenologie und phänomenologische Philosophie:

- Erstes Buch: Allgemeine Einführung in die reine Phänomenologie. 2. ${ }^{a} \mathrm{ed}$. Walter Biemel (ed.). Husserliana, III. Haag: Martinus Nijhoff, 1950.

- Zweites Buch: Phänomenologische Untersuchungen zur Konstitution. Marly Biemel (ed.). Hussserliana, IV. Haag: Martinus Nijhoff, 1952.

- Drittes Buch: Die Phänomenologie und die Fundamente der Wissenschaft. Marly Biemel (ed.). Husserliana, V. Haag: Martinus Nijhoff, 1952.

HusserL, Edmund (1976). Die Krise der europäischen Wissenschaft und die transzendentale Phänomenologie. Eine Einleitung in die phänomenologische Philosophie. Walter Biemel (ed.). 2. ${ }^{a}$ ed. Husserliana, VI. Haag: Martinus Nijhoff.

Husserl, Edmund (1959). Erste Philosophie (1923/1924). Zweiter Teil. Theorie der phänomenologischen Reduktion. Rudolf Boehm (ed.). Husserliana, VIII. Haag: Martinus Nijoff. 
HusserL, Edmund (1962). Phänomenologische Psychologie. Vorlesungen Sommersemester 1925. Walter Biemel (ed.). Husserliana, IX. Haag: Martinus Nijhoff.

HusserL, Edmund (1977). Transzendentale und formale Logik. Versuch einer Kritik der logischen Vernunft. P. Janssen (ed.). Husserliana, XVII. Den Haag: Martinus Nijhoff.

HusșER, Edmund (1975-1984). Logische Untersuchungen:

- Erster Band: Prolegomena zur reinen Logik. Elmar Holenstein (ed.). Husserliana, XVIII. Den Haag: Martinus Nijhoff, 1975.

- Zweiter Band. Erster Teil. Untersuchungen zur Phänomenologie und Theorie der Erkenntnis. Ursula Panzer (ed.). Husserliana, XIX,1. The Hague/Boston/ Lancaster: Martinus Nijhoff Publishers, 1984.

- Zweiter Band. Zweiter Teil. Untersuchungen zur Phänomenologie und Theorie der Erkenntnis. Husserliana, XIX,2. Ursulal Panzer (ed.). The Hague/ Boston/Lancaster: Martinus Nijhoff Publishers, 1984.

Hussert, Edmund (1987). Aufsätze und Vorträge (1911-1921). Thomas Nenon \& Hans Rainer Sepp (eds.). Husserliana, XXV. Dordrecht/Boston/Lancaster: Martinus Nijhoff Publishers.

HusserL, Edmund (1979). Aufsätze un Rezensionen (1890-1910). Hua XXII. The Hague/Boston/London.

HusSERL, Edmund (1984). Einleitung in die Logik und Erkenntnistheorie. Vorlesungen 1906-1907. Ulrich Melle (ed.). Husserliana, XXIV. Dordrecht/Boston/Lancaster: Martinus Nijhoff Publishers.

HusSERL, Edmund (1993). Die Krisis der europäischen Wissenschaften und die transzendentale Phänomenologie. Ergänzungsband. Texte aus dem Nachlass, 19341937. Reinhold N. Smid (ed.). Husserliana, XXIX. Dordrecht: Kluwer Academic Publishers.

HusSERL, Edmund (2001). Allgemeine Erkenntnistheorie. Vorlesung 1902/1903. Elisabeth Schuhmann (ed.). Husserliana: Materialbände, III. Dordrecht/Boston/London: Kluwer Academic Publishers.

KeRN, Isso (1964). Husserl und Kant. Eine Untersuchung über Husserls Verhältnis zu Kant und zum Neukantismus. Den Haag: Martinus Nijhoff.

Kockelmans, Joseph J. (1994), Edmund Husserl's Phenomenology. Indiana: Purdue University Press.

'LOHMAR, Dieter (2000). Edmund Husserls 'Formale und transzendentale Logik'. Darmstadt: WissenschaFTLiche Buchgesellschaft.

Mohanty, J. N. (1989). Psychologism. In: Mark A. Notturno (ed.), Perspectives on Psychologism. Leiden/New York/Kobenhavn/Köln: E. J. Brill, pp. 1-10.

Mohanty, J. N. (2003). The concept of 'Psychologism' in Frege and Husserl. In: Dale Jacquette (ed.), Philosophy, Psychology and Psychologism. Critical and Historical Readings on the Psychological Turn in Philosophy. Dordrecht/Boston/ London: Kluwer Academic Publishers, pp. 113-130. 
RINofnen, Sonja (1997). Das Psychologismusproblem und die Idee einer phänomenologischen Wissenschaft. Phänomenologische Forschungen. Neue Hefte 2, 1. Halbband, 1997, 3-34.

SeEbohm, Thomas M. (1989). The more Dangerous Disease: Transcendental Psychologism, Anthropologism, and Historism. In: Mark A. Notturno (ed.), Perspectives on Psychologism. Leiden/New York/Kobenhavn/Köln: E. J. Brill pp. 11-31.

Sefborm, Thomas M. (1991). Psychologism Revisited. In: T. Seebohm, D. Föllesdall \& J. N. Mohanty (eds.), Phenomenology and the Formal Sciences. Dordrecht/ Boston/London: Kluwer Academic Publishers, pp. 149-182.

STRÖCKER, Elisabeth (1987). Phänomenologie und Psychologie. Die Frage ihrer Beziehung bei Husserl. In: Elisabeth Ströcker (ed.), Phänomenologische. Studien. Frankfurt am Main: Vittorio Klostermann, pp. 94-114.

\section{ABSTRACT}

The present text reviews the treatment of psychologism after the 'Logical Investigations'. Its aim is to fill a gap in the Husserl an research about this topic, which, focusing on the above-mentioned work, provides a homogeneous treatment of the later position without considering the possibility of its evolution. A primary result of our investigation is the distinction of six stages in the above-mentioned development. These are established in correlation to the Husserlian development in connected themes such as the theory of psychology, of the reduction and of the self-constitution of subjectivity. In this context, the Husserlian development around 1927 concerning the idea of an final understanding and final overcoming of the transcendental psychologism stands out, as does the later identification in 'Crisis' between transcendental phenomenology and psychology. Such identification revises the presupposition present from 1906 onwards that the phenomenological psychology is included in the context of a regional ontology, which puts aside the idea, decisive in 1927 , of a 'refined' transcendental psychologism made possible by the development of this psychology. 